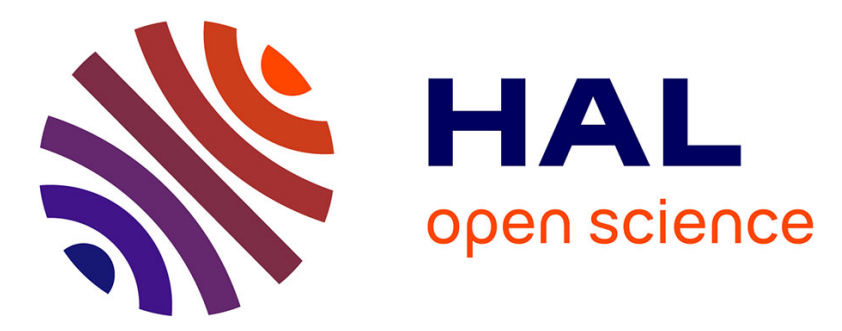

\title{
Embryos of TTGs in Gore Mountain garnet megacrysts from water-fluxed melting of the lower crust
}

S. Ferrero, I. Wannhoff, Oscar Laurent, C. Yakymchuk, R. Darling, B. Wunder, A. Borghini, P.J. O’Brien

\section{- To cite this version:}

S. Ferrero, I. Wannhoff, Oscar Laurent, C. Yakymchuk, R. Darling, et al.. Embryos of TTGs in Gore Mountain garnet megacrysts from water-fluxed melting of the lower crust. Earth and Planetary Science Letters, 2021, 569, pp.117058. 10.1016/j.epsl.2021.117058 . hal-03436618

\section{HAL Id: hal-03436618 https://hal.science/hal-03436618}

Submitted on 24 Nov 2021

HAL is a multi-disciplinary open access archive for the deposit and dissemination of scientific research documents, whether they are published or not. The documents may come from teaching and research institutions in France or abroad, or from public or private research centers.
L'archive ouverte pluridisciplinaire $\mathbf{H A L}$, est destinée au dépôt et à la diffusion de documents scientifiques de niveau recherche, publiés ou non, émanant des établissements d'enseignement et de recherche français ou étrangers, des laboratoires publics ou privés. 


\section{Embryos of TTGs in Gore Mountain garnet}

\section{megacrysts from water-fluxed melting of the lower}

\section{crust}

S. Ferrero ${ }^{1,2}$, I. Wannhoff ${ }^{3}$, O. Laurent ${ }^{4,5}$, C. Yakymchuk ${ }^{6}$, R. Darling ${ }^{7}$, B. Wunder ${ }^{8}$, A. Borghini ${ }^{1}$ and P. O’Brien ${ }^{1}$.

${ }^{1}$ Universität Potsdam, 14476 Potsdam-Golm, Germany; sferrero@uni-potsdam.de; borghini@uni-potsdam.de; obrien@uni-potsdam.de

${ }^{2}$ Museum für Naturkunde (MfN), 10115 Berlin, Germany;

${ }^{3}$ Freie Universität Berlin, 12249 Berlin, Germany; iris.wannhoff@fu-berlin.de

${ }^{4} \mathrm{ETH}$, Zurich, Department Erdwissenschaften, Institute for Mineralogy and Petrology, 8092 Zürich, Switzerland

${ }^{5}$ CNRS, Observatoire Midi-Pyrénées, Géosciences Environnement, 31400 Toulouse, France; oscar.laurent@Get.omp.eu

${ }^{6}$ University of Waterloo, Waterloo, ON N2L 3G1, Canada; chris.yakymchuk@uwaterloo.ca

7 SUNY College at Cortland, NY 13045,US; robert.darling@cortland.edu

${ }^{8}$ GFZ, German Research Centre for Geosciences, 14473 Potsdam, Germany; wunder@gfz-potsdam.de

\section{Abstract}


The garnet megacrysts of Gore Mountain (Adirondacks, US) are world-renown crystals due to their size, up to $1 \mathrm{~m}$ in historical record, which makes them the largest known garnets on the planet. We show here that they are also host to the first primary inclusions of trondhjemitic melt found in natural mafic rocks. The petrological and experimental investigation of the inclusions, coupled with phase equilibrium modelling, shows that this melt is the result of $\mathrm{H}_{2} \mathrm{O}$-fluxed partial melting at $\mathrm{T}>900^{\circ} \mathrm{C}$ of a lower crustal gabbro. The compositional similarity between the trondhjemitic melt inclusions and tonalitictrondhjemitic-granodioritic (TTGs) melts makes these inclusions a direct natural evidence that melting of mafic rocks generates TTG-like melts, and provide us with the possibility to clarify processes responsible for the formation of the early continental crust. These TTG embryos represent the trondhjemitic end-member of the melts whose emplacement at upper crustal levels, after being modified by mixing and crystallization-related processes, leads to the formation of the TTG terranes. Moreover, our study shows how the melt from $\mathrm{H}_{2} \mathrm{O}$-fluxed melting of mafic lower crust has mismatched major and trace element signatures, previously interpreted as evidence of melting at very different pressures. This poses serious limitations to the established use of some chemical features to identify the geodynamic settings (e.g. subduction versus thickened crust) responsible for TTG generation and the growth of early crust.

\section{Introduction}

The garnet megacrysts of Barton mine, Gore Mountain (Adirondack Highlands, USA) are world-renowned both among petrologists and collectors for their exceptional size - $1 \mathrm{~m}$ crystals are recorded historically, making them some of the largest known 
garnets on the planet, and for their industrial use as abrasive material, with mining having occurred continuously from 1878 to 1983 (Kelly and Darling, 2008). These specimens also display another crucial feature: the presence of silicate melt preserved as crystallized and glass-bearing inclusions of primary nature. Garnet is one of the most common and widely stable peritectic phases in metamorphic crustal rocks (Baxter et al., 2013), and it has been proven to be able to trap and preserve the melt resulting from crustal melting in more than 40 localities worldwide (Nicoli and Ferrero, 2021; Ferrero et al., 2018). Although melt inclusions (MI) are being increasingly recognized as a common feature of high-grade terranes (Bartoli and Cesare, 2020), the Gore Mountain inclusions are unique because they contain trondhjemitic melt inclusions in a mafic source rock, a feature never reported in previous studies on $\mathrm{Ml}$ in metamorphic rocks.

Partial melting of a mafic sources has been invoked for the formation of the tonalite, trondhjemite and granodiorite (TTG) rocks, suites of sodium-rich, potassium-poor granitoids, which form the bulk of early Earth's preserved crust (see Moyen and Martin, 2012 and references therein for a thorough review on the subject). The formation and stabilization of the earliest continental crust are key aspects of planetary evolution that can create conditions suitable for the development of complex life. Constraining the origin of TTGs is, therefore, important for models of early evolution of our planet.

Although the source rocks of TTGs are commonly inferred to be hydrated mafic rocks (Moyen and Martin, 2012), there are no known examples of melt inclusions in garnet in such metabasites. TTGs have been proposed to be generated by partial melting of subducted mafic rocks at very high pressures (HP, >2.5 GPa, Moyen, 2011) or at much shallower lower crustal conditions (<1.5 GPa) via amphibole-breakdown (Johnson et al., 
2013, 2017) or water-fluxed melting (Pourteau et al., 2020). Other models propose that TTG magmas result from fractional crystallization of intermediate-mafic magmas (Jagoutz et al., 2013; Smithies et al., 2019) possibly associated with crystal-liquid unmixing in shallow magma chambers feeding silicic eruptions (Laurent et al., 2020). The formation mechanisms of the parental TTG magmas at lower crustal depths have been investigated via geochemical and petrological characterization of TTG rocks emplaced at shallower levels (e.g. Moyen and Martin, 2012), forward modelling of putative analogues for source rocks exposed in Archean terranes (Johnson et al., 2017; Smithies et al., 2019), or using experiments (e.g. Laurie and Stevens, 2012; Qian and Hermann, 2013) and thermodynamic modelling (e.g. Kendrick and Yakymchuk, 2020).

Our finding provides a novel tool, i.e., the study of preserved MI in high-grade rocks, for the investigation of melting mechanisms in a natural mafic source region. More importantly, despite the fact that the target rocks are not Archean in age and TTG bodies are absent in the area, the similarities between the targeted Ml and the TTG magmas both in terms of composition and genetic process makes of the present case study the missing link between nature, experiments and modelling results on the model of TTG petrogenesis via mafic melting.

\section{Sample description}

The rock investigated in this study is a garnet amphibolite of Mesoproterozoic age sampled in the pit 1 of the currently inactive mining site of Barton Mine, now Garnet Mine Tours in the Adirondacks $\left(43^{\circ} 40^{\prime} 56^{\prime \prime} \mathrm{N}, 74^{\circ} 2^{\prime} 51^{\prime \prime} \mathrm{W}\right.$, Fig. 1a,b), which is an outlier of the Grenvillian orogeny (Rivers, 1997). The most apparent feature of the investigated rocks 
is the presence of garnet megacrysts. They form large porphyroblasts, subhedral to euhedral in shape (Fig. 1c), with size visible at the present day in the outcrop of $\leq 35 \mathrm{~cm}$ in diameter (Kelly and Darling, 2008). Despite their size, the garnet porphyroblasts show a remarkably homogenous composition with high almandine and pyrope components and minor grossular (Alm ${ }_{44} \operatorname{Prp}_{42} \mathrm{Grs}_{14} \mathrm{Sps}_{1}$, Supplementary table $\mathrm{S} 1$; for details on analytical methods and techniques see the Supplementary Material). Almost every garnet is entirely surrounded by a shell of coarse-grained idiomorphic hornblende, several $\mathrm{cm}$-wide (Fig. 1c). The crystallographic faces of garnet appear generally preserved at the garnethornblende interface at the outcrop and hand sample scale. Locally however garnet can also be surrounded by sub-millimetric symplectitic rims containing fine-grained hornblende, plagioclase, orthopyroxene and minor biotite, that formed during retrogression (mineral compositions are in Supplementary table S1; see also Hollocher, 2008). Garnet porphyroblasts and hornblende shells are hosted in a granoblastic matrix composed mainly of plagioclase and hornblende (the latter identical in major element compositions to the shell hornblende; Supplementary Table S1), plagioclase and orthopyroxene (Fig. 1c), with minor biotite and pyrite.

Previous authors generally agree that these amphibolites are the result of highgrade metamorphism during the collapse of the Ottawan orogen at $1050 \mathrm{Ma}$ (e.g. McLelland and Selleck, 2011). The protolith is an olivine-bearing gabbro exposed adjacent to the amphibolites (Fig. 1b) and was originally emplaced at $\sim 1150 \mathrm{Ma}$ as part of an anorthosite-mangerite-charnockite-granite (AMCG) suite in the basement of the Adirondacks (Fig. 1a; Rivers, 1997). The extreme grain size of the rock, especially of the garnet porphyroblasts, coupled with the abundance of amphibole with respect to the 
gabbro protolith, has prompted several authors to propose the flux of a "copious amount of fluid" during metamorphism (McLelland and Selleck, 2011). This likely occurred along a shear zone at the contact between gabbro and syenite (Fig. 1b), inferred to be a preferential pathway for fluid ingress (Goldblum and Hill, 1992).

\section{Results}

\subsection{Crystallized melt inclusions}

The garnet megacrysts contain a relatively large amount of polycrystalline inclusions along with crystallographically-oriented rutile needles (Fig. 2a, b). Polycrystalline inclusions are distributed as clusters in the inner portion of the garnet, which is unequivocal evidence of entrapment during garnet growth (Ferrero et al., 2018 and references therein); these inclusions are therefore primary in nature. The inclusions are aggregates of micrometric crystals in cavities of mostly isometric shape with size $\leq 50 \mu \mathrm{m}$ across, with the smallest inclusions $(<15 \mu \mathrm{m})$ displaying negative crystal shapes (i.e. mimicking the shape of the host garnet; Fig. 2b, c, d, e). Many inclusions have elongated tubular shapes with lengths of $\leq 150 \mu \mathrm{m}$ and diameters of $\leq 10 \mu \mathrm{m}$ (Fig. 1b), parallel to rutile needles. Decrepitation cracks are generally absent in the inclusions regardless their shape.

A combination of Raman spectroscopy and Field Emission Gun (FEG) electron probe microanalysis (EPMA) has shown that most of the inclusions contain an assemblage consisting of cristobalite (Fig. 2e, f; already identified by Darling et al., 1997), quartz or tridymite, plus kumdykolite (an albite polymorph; Ferrero et al., 2016) and one or both of the $\mathrm{OH}$-bearing phases anthophyllite and pargasite (Fig. 2c, d, e, f). Minor 
amounts of phlogopite and osumilite are also present. Orthopyroxene, apatite, ilmenite and rutile needles may occur in the $\mathrm{Ml}$ and are interpreted as trapped accessory phases, as they are also present as mineral inclusions in the host garnet. The association of polymorphs of silica and feldspars plus $\mathrm{OH}$-bearing phases is characteristic of nanogranitoids, i.e., crystallized MI in metamorphic rocks (e.g. Bartoli et al., 2016; Ferrero et al., 2018). One inclusion contains glass along with pargasite and accessory minerals; the glass is probably residual after partial crystallization of the melt originally trapped in the inclusion (Fig. 2f, g; see also glass composition in table 1). Cristobalite is present both as a crystallization product in the nanogranitoids and in association with rutile or ilmenite in a second type of polycrystalline inclusions, whose overall composition is incompatible with a former melt nature and thus will not be investigated further.

\subsection{Experimental re-homogenization and melt chemistry}

Multiple re-heating experiments in the temperature $(\mathrm{T})$ range $900-950^{\circ} \mathrm{C}$ under confining pressure $(\mathrm{P})$ of 1.0-1.5 GPa were performed using a piston cylinder press to re-homogenize the crystallized inclusions to glass, following the method devised by Bartoli et al. (2013; see also Supplementary Material). Experimental parameters and observations on the products of each run are listed in Fig. 3a. After the run at $900^{\circ} \mathrm{C}$ (experiment GM3), the inclusions show no evidence of re-melting, i.e. glass is absent. At $925^{\circ} \mathrm{C}$ (GM5) only the smallest inclusions $(<2 \mu \mathrm{m})$ appear to be completely rehomogenized, whereas most inclusions contain glass in association with daughter phases such as kumdykolite and / or amphibole, and were therefore interpreted as having only undergone partial re-melting. Complete re-homogenization of the inclusions is instead 
common after re-heating at temperature $(\mathrm{T})=940^{\circ} \mathrm{C}(\mathrm{GM} 7, \mathrm{GM} 8, \mathrm{GM} 9)$, where nanogranitoids turn into a homogenous hydrous glass (Fig. 3b) often containing trapped phases such as orthopyroxene (Fig. 3c), cristobalite, rutile and more rarely ilmenite (Table 1). At $950^{\circ} \mathrm{C}$ (GM1) the nanogranitoids are again completely re-homogenized, but cracks are common in the host and locally melt and garnet interact, which indicates disequilibrium between melt and host (Ferrero et al., 2018) and suggests that $950^{\circ} \mathrm{C}$ is higher than the original entrapment $\mathrm{T}$ of the inclusions (see discussion).

The fully re-homogenized inclusions from the experiments at $940^{\circ} \mathrm{C}$ were analyzed via EPMA on 7 inclusions (Fig., 4a; Table1). The resulting glass, after alkali-loss correction (see details on the procedure in Supplementary Material), is a trondhjemite with average $\mathrm{SiO}_{2}=71.89 \mathrm{wt} \% ; \mathrm{Na} 2 \mathrm{O} / \mathrm{CaO}=2.54$ and $\mathrm{K}_{2} \mathrm{O} / \mathrm{Na}_{2} \mathrm{O} \approx 0.20$, low magnesium number $\left(\mathrm{Mg \#}=\left[\mathrm{molar} \mathrm{Mg} /\left(\mathrm{Mg}+\mathrm{Fe}^{2+}{ }_{\text {tot }}\right)\right]=0.39\right)$ and peraluminous character [Aluminium Saturation Index $(\mathrm{ASI})=\mathrm{Al} /(\mathrm{Ca}+\mathrm{Na}+\mathrm{K})=1.34]$. The $\mathrm{H}_{2} \mathrm{O}$ content, measured by EMP difference, is around $4.28 \mathrm{wt} \%$.

The trace element content of isometric nanogranitoids located below the surface was measured via Laser Ablation Inductively Coupled Plasma Mass Spectrometry (LAICP-MS) and the contribution of the host garnet subtracted after the analytical session (see methods in Supplementary Material; the whole trace element dataset is visible Table S2). Elements enriched in the host (e.g. Y, Heavy Rare Earths Elements - HREE) with respect to the inclusions are not quantifiable with this method due to the dominant signal from the host (Ferrero et al., 2018). The polycrystalline inclusions show strong enrichment in some High Field Strength Elements (HFSE), like Zr, Hf and Ti compared to the protolith gabbro (Fig. 4b), as well as enrichments of $\mathrm{Pb}, \mathrm{U}, \mathrm{Th}, \mathrm{Zn}$ and Rare Earths elements (REE) 
from La to Gd (Fig. 4c). Both melt and gabbro show on average a similar positive Eu anomaly (Fig. 4c).

\subsection{Phase equilibrium modelling}

Phase equilibrium modelling was used to constrain independently the pressuretemperature $(P T)$ conditions of partial melting and peak metamorphism, as well as quantify the concentration of $\mathrm{H}_{2} \mathrm{O}$ in the system required to generate the observed mineral assemblage in the garnet amphibolites of Gore Mountain. A key assumption of this modelling approach is the achievement of chemical equilibrium in the system (Lanari and Duesterhoeft, 2019); the macroscopic spatial distribution of garnet at the outcrop scale at Gore Mountain is heterogeneous and the diffusive length scale required to maintain chemical equilibrium between garnet and its matrix is unclear. Keeping this limitation in mind, we use phase equilibrium modelling to provide a first-order assessment of the $P$ $T$ - composition $(X)$ conditions required for development of the observed mineral assemblages and this approach independently complements other estimates of peak metamorphic conditions, such as melt re-homogenization temperatures (this study) and trace element thermometry of accessory minerals (Shinevar et al., 2021). The detailed modelling methods are presented in the supplementary material.

A temperature-composition $\left(\mathrm{H}_{2} \mathrm{O}\right)$ phase diagram was calculated at $1.0 \mathrm{GPa}$ for the inferred protolith (olivine gabbro) over a range of $\mathrm{H}_{2} \mathrm{O}$ concentrations-ranging from essentially dry to $\mathrm{H}_{2} \mathrm{O}$-saturated at the wet solidus-to constrain the stability of the peak metamorphic assemblage (garnet, hornblende, orthopyroxene, plagioclase and melt). Orthopyroxene in equilibrium with anatectic melt is predicted to be stable at $>800^{\circ} \mathrm{C}$ (Fig. 
5a), which is a lower limit on the peak temperature. The absence of quartz from inferred peak assemblage further restricts temperatures to $>850^{\circ} \mathrm{C}$ (Fig. 5a). The modelled concentration of $\mathrm{H}_{2} \mathrm{O}$ in the system during the metamorphic peak (at $1.0 \mathrm{GPa}$ ) is restricted to $<4 \mathrm{wt} \%$ by the presence of plagioclase and to $>1 \mathrm{wt} \% \mathrm{H}_{2} \mathrm{O}$ by the solidus at $850^{\circ} \mathrm{C}$ (Fig. 5a). An additional constraint on the temperature and $\mathrm{H}_{2} \mathrm{O}$ content of the system at peak metamorphism is provided by comparing the observed proportion of garnet in the garnet amphibolites ( 13 vol.\%; McLelland and Selleck, 2011) with the modelled amount (calculated as mol. \% in the modelling, which is roughly equivalent to vol. $\%$ on a one-oxide molecular basis). In general, using mineral proportions is considered preferable to using mineral compositions to constrain peak $P-T$ conditions in high-temperature metamorphic rocks (e.g. White et al., 2011). Using this approach, a modelled 13 mol.\% of garnet in the system is restricted to $>870^{\circ} \mathrm{C}$ and compositions with $\sim 3$ wt $\% \mathrm{H}_{2} \mathrm{O}$ (Fig. 5a). This indicates that the inferred peak assemblage requires substantial $\mathrm{H}_{2} \mathrm{O}$ influx into the system when compared with the composition of the inferred protolith $\left(\sim 0.44\right.$ wt $\% \mathrm{H}_{2} \mathrm{O}$, McLelland and Selleck, 2011). The temperatures of $>900^{\circ} \mathrm{C}$ at $1.0 \mathrm{GPa}$ in the model yield the observed proportion of garnet (Fig. 5a). Note that the modelled phase assemblage field that contains the observed amount of garnet is also predicted to contain a minor amount of clinopyroxene $(<8 \mathrm{~mol} . \%$ at $1.0 \mathrm{GPa})$, which is absent from the Gore Mountain garnet amphibolites. The significance of clinopyroxene to the modelling results is discussed below.

Using the estimated $3 \mathrm{wt} \% \mathrm{H}_{2} \mathrm{O}$ in the system at the metamorphic peak (Fig. 5a) a pressure-temperature phase diagram was calculated to further constrain the metamorphic peak (Fig. 5b). The inferred peak metamorphic assemblage for the Gore 
Mountain garnet amphibolites is restricted to a small field at $810-890^{\circ} \mathrm{C}$ and $0.9-1.0 \mathrm{GPa}$. However, the maximum molar proportion of garnet in this field is $7 \mathrm{~mol} . \%$, which is roughly half of the observed amount. To achieve a modeled $13 \mathrm{~mol} . \%$, garnet requires a predicted mineral assemblage with a minor amount of clinopyroxene (Fig. 5b). The modelled stability of clinopyroxene in anatectic metabasites is usually overestimated by current phase equilibrium modelling techniques. This reflects a limitation of the modelling in which the partitioning of $\mathrm{Ca}$ (and some other cations) between amphibole and clinopyroxene does not reproduce natural parageneses accurately (Forshaw et al., 2019). Therefore, this limitation will influence amphibole-rich rocks such as the Gore Mountain garnet amphibolites. Considering this model limitation, if we permit a small amount $(<8 \mathrm{~mol} . \%)$ of model clinopyroxene into the peak assemblage for the investigated rocks, then the estimated peak $P-T$ conditions are restricted to $\sim 1.0 \mathrm{GPa}$ (based on the $13 \mathrm{~mol} . \%$ garnet isopleth) and to temperatures $850-950^{\circ} \mathrm{C}$. Along the 13 mol.\% garnet isopleth (Fig. $5 \mathrm{~b}$ ), the modeled amount of clinopyroxene decreases from $\sim 8 \mathrm{~mol} . \%$ at $950^{\circ} \mathrm{C}$ to $\sim 2 \mathrm{~mol} . \%$ at $850^{\circ} \mathrm{C}$ (Supplementary Fig. S1d). Therefore, we consider temperatures of $>900^{\circ} \mathrm{C}$ permissible by the phase equilibrium modelling, with the caveat that the stability of clinopyroxene is a source of uncertainty in modelling partial melting of amphibole-rich rocks. These modelled temperatures are consistent with the temperature of $\mathrm{MI}$ rehomogenization $\left(900-950^{\circ} \mathrm{C}\right.$ ) and yield a predicted $20-25$ mol.\% melt (Supplementary Fig. S1a).

\section{Discussion}

\subsection{Silicate melt at Barton mine}


Polycrystalline inclusions are present in the garnet megacrysts of Barton mine at Gore Mountain. Their phase assemblages and successful re-homogenization via experimental re-heating, coupled with the presence of preserved glass in one inclusion, demonstrate that such inclusions were originally droplets of melt, now partially to totally crystallized to nanogranitoids. Due to their overall trondhjemitic composition, such inclusions will be hence forward called "nanotrondhjemites" in keeping with the common use in nanogranitoid nomenclature (Bartoli and Cesare, 2020). A melt origin for the cristobalite-bearing polycrystalline inclusions in the garnet megacrysts was already proposed by Darling et al. (1997), but no melt compositions were retrieved to support this hypothesis at the time. More recently, Shinevar et al. (2021) proposed the production of a limited amount of melt during the formation of garnet megacrysts at Barton Mine. Moreover, in the Adirondack Highlands nanogranitoids were previously reported in the metapelitic gneisses of Port Leyden (Darling, 2013). Preliminary investigations also show their presence also in garnets from Hooper mine (Ferrero, unpublished data), a garnet mine active until 1928 (Darling, pers.comm.), suggesting that partial melting in the area may be more common than previously thought.

Although the finding of glass-bearing nanogranitoids is a compelling evidence for the (former) presence of melt in the garnet megacrysts, clear leucosome domains are not conspicuous at the outcrop scale. Leucocratic pockets, several $\mathrm{cm}$ across in size, are anyway often visible in pit 1 (Fig. 6a, b). They are mainly composed of coarse-grained plagioclase \pm orthopyroxene, and always closely associated with the garnet megacrysts. Commonly these pockets are entirely enclosed within the amphibole shell surrounding the megacrysts, making their formation likely associated to both garnet and amphibole 
growth (Fig. 6). Such pockets could either be breakdown products of garnet with contribution from the amphibole, or represent crystallized melt. The first possibility can be excluded because the retrograde reaction between garnet and amphibole in these rocks generates submillimetric symplectites of plagioclase + orthopyroxene + hornblende + biotite (Hollocher, 2008), very different both in grain size and assemblage with respect to the leucocratic pockets. This leaves only a melt-related origin for the leucocratic pockets. Hollocher (2008) ruled out also this possibility because their composition is incompatible with a melt, but this argument fails to consider that leucosome domains generally do not preserve a true melt composition due to interactions with the surrounding mineral phases, fractional crystallization and melt extraction upon cooling. These pockets may be crystallized pods of originally trondhjemitic melt now modified, a hypothesis which however requires further investigation. Nevertheless, such pockets would only account for $\leq 5$ melt vol\%, whereas the phase equilibria modelling predicts significantly higher melt volumes $(\sim 20-25$ vol.\%) to be produced at the metamorphic peak conditions (Supplementary Fig. S1). The "missing" melt (15-20 vol\%) could have (re)crystallized as part of the matrix, or alternatively, left the source rock as often observed in migmatitic terranes (e.g. Brown et al., 2016). However, evidence of significant movements of melt out of the rock are absent, and indeed both garnet amphibolites and the protolith gabbro show identical bulk compositions (except for higher $\mathrm{H}_{2} \mathrm{O}$ in the former, McLelland and Selleck, 2011), which is overall incompatible with melt loss (see also Shinevar et al., 2021).

\subsection{Peculiar findings in nanotrondhjemites}


The products visible in the Gore Mountain nanotrondhjemites often include unusual phases such as cristobalite, tridymite and kumdykolite and, in one case, glass. The mineral phases are polymorphs of quartz and feldspar respectively, and were already reported in nanogranitoids hosted in rocks with widely different protoliths (from ultramafic to felsic) and partially melted under extremely variable $\mathrm{P}$ and $\mathrm{T}$ conditions, i.e., low to ultrahigh $\mathrm{P}$ and 700 to $1100^{\circ} \mathrm{C}$ (Ferrero and Angel, 2018). These phases appear to be metastable products of melt crystallization resulting from "peculiar undercooled and supersaturated conditions achieved on cooling by a melt confined in a small cavity" (Ferrero and Angel, 2018 and references therein), with crystallization kinetics of the melt likely playing a fundamental role in their formation rather than $\mathrm{P}$ and $\mathrm{T}$ conditions. Polymorphs are known to disappear, i.e. revert to their most common counterparts quartz and albite in case of inclusion reopening/decrepitation (Ferrero and Angel, 2018). Thus, their persistence in inclusions can be regarded as a strong evidence that the $\mathrm{Ml}$ are preserved and thus the melt trapped in them maintain its original composition (Bartoli and Cesare, 2020).

Glass, visible in the present study only in one partially crystallized inclusion, is commonly observed to form in volcanic rocks as result of fast cooling: however, fully and partially crystallized $\mathrm{MI}$ are reported in several case studies of slowly cooled regional migmatites (Cesare et al., 2015; Ferrero et al., 2018), ruling out this possibility as the only way to create glass in natural inclusions. The presence of glass can thus be regarded as another clear evidence, besides the presence of polymorphs, that metastability may be a rather common condition attained on cooling (Ferrero and Angel, 2018) in inclusions of viscous, silica-rich melt such as the ones here investigated. 


\subsection{Melting at temperature in excess of $900^{\circ} \mathrm{C}$ in the Adirondack Highlands}

The nanotrondhjemites re-homogenize completely at $\mathrm{T} \geq 940^{\circ} \mathrm{C}$ and $\mathrm{P} \geq 1.0 \mathrm{GPa}$, at $\mathrm{T}$ higher than the classic estimate of metamorphic peak $\mathrm{T}$ available in the Adirondack Highlands, i.e., $800-850^{\circ} \mathrm{C}$ and $0.65-0.86 \mathrm{GPa}$ (summarized by Darling and Peck, 2016). Previous studies (Ferrero et al., 2018; 2021) have shown that the PT conditions at which the inclusions re-homogenize completely without evidence of decrepitation and/or melthost interaction correspond to those of the partial melting event responsible for the formation of the inclusions (Ferrero et al., 2018 for further details). In particular, the rehomogenization T corresponds to the melting condition experienced by the rock, whereas the experimental confining $\mathrm{P}$ (applied to prevent $\mathrm{Ml}$ decrepitation during re-heating) is equal to or higher with respect to the original melting $P$ (Ferrero et al., 2018). This is also supported by a wealth of recent nanogranitoid studies where experimental $P-T$ conditions of successful re-homogenization correspond to independently calculated partial melting conditions, e.g. classic geothermobarometry or phase equilibrium modelling (see e.g. Bartoli et al., 2013; Ferrero et al., 2018 and references therein; 2021). Thus, whereas the primary nature of the inclusions constrains the formation of garnet megacrysts at suprasolidus conditions, their re-homogenization conditions suggest ultrahigh temperature (UHT) during melting, i.e. at $\mathrm{T}$ in excess of $900^{\circ} \mathrm{C}$. An $\mathrm{UHT}$ regime during garnet formation is also permissible with the results of phase equilibrium modelling (Fig. $5 a, b)$. Phase equilibrium modelling and the similarities with previous nanogranitoid studies (Cesare et al., 2015) furthermore suggests that both melt and garnet are products 
of the same partial melting reaction, pointing toward a peritectic origin for the garnet megacrysts.

Although our results are at odds with the bulk of existing data on the metamorphic history of the area, we are not alone in supporting the possibility of UHT conditions in the Adirondack Highlands. Shinevar et al. (2021) provide strong mineralogical and phase equilibria evidence in support of ultrahigh $\mathrm{T}$ conditions $\left(950 \pm 40^{\circ} \mathrm{C}\right)$ at Barton mine, whereas recent phase equilibrium modelling on Ledge Mountain metapelitic migmatites (30 km NNW of Barton Mine) points toward metamorphic peak conditions of $>1000^{\circ} \mathrm{C}$ at 1.3-1.8 GPa (Davis et al., 2020). These new results call for a reappraisal of the metamorphic peak conditions experienced by the Gore Mountain garnet amphibolites and, more in general, by the rocks in the Adirondack Highlands. Further support to our interpretation that melting occurred at $\mathrm{T}>900^{\circ} \mathrm{C}$ is lent by the striking similarity between what we observe in the garnet amphibolites at Barton mine and the products of mafic melting experiments. A trondhjemitic melt is indeed observed to form at $\mathrm{T}>900^{\circ} \mathrm{C}$ at $1.3-$ 1.5 GPa along with garnet, amphibole, plagioclase, clinopyroxene and orthopyroxene in melting experiments on starting compositions similar to the gabbro protolith inferred for the garnet amphibolites (Qian and Hermann, 2013; see also van der Laan and Wyllie, 1992). With the exception of clinopyroxene (probably also due to the slightly higher P ), the experimental products correspond remarkably to the phase assemblage $\mathrm{Grt}+\mathrm{Hbl}+$ $\mathrm{PI}+$ Opx + Melt observed in the garnet amphibolite

\section{4 $\mathrm{H}_{2} \mathrm{O}$-fluxed incongruent melting in the lower crust}


Incongruent melting that generates garnet in crustal rocks is generally expected to be a fluid-absent melting reaction. At Gore Mountain however the presence of a $\mathrm{H}_{2} \mathrm{O}$-rich fluid is necessary to explain both melt production and the extensive hornblende growth (Fig. 1c) from metamorphism of a dry gabbro; moreover, garnet amphibolites have higher $\mathrm{H}_{2} \mathrm{O}$ content with respect to their gabbro protolith (see paragraph 4.1). Phase equilibrium modelling of the metagabbro at $1.0 \mathrm{GPa}$ demonstrates that the growth of the observed $\sim 13$ vol. \% peritectic garnet requires the influx of $\sim 3 \mathrm{wt} \% \mathrm{H}_{2} \mathrm{O}$ at temperatures $>850^{\circ} \mathrm{C}$ (Fig. 5a, b). Thus, both modelling results and petrographic evidence point to open-system conditions during melting. Our interpretation is that the main components of gabbro (plagioclase, clinopyroxene, olivine) reacted with a $\mathrm{H}_{2} \mathrm{O}$-rich fluid to produce the assemblage visible in the garnet amphibolite (i.e., garnet, amphibole, plagioclase, orthopyroxene and melt), which also corresponds to the (near?) peak metamorphic assemblage visible in Fig. 5. Both presence of $\mathrm{Ml}$ in the inner portion of garnet megacrysts and the lack of prograde zoning (Hollocher, 2008) support garnet growth entirely at (or close to) metamorphic peak conditions, i.e., at $>900^{\circ} \mathrm{C}$ and $\sim 1.0 \mathrm{GPa}$.

The trace element content of the melt resembles that of the gabbro, confirming the latter as the melt source. The most notable geochemical feature of the melt is the strong enrichment in Th, $\mathrm{U}$ and some High Field Strength Elements (HFSE), like $\mathrm{Zr}, \mathrm{Hf}$ and $\mathrm{Ti}$ compared to the source gabbro (Fig. 4b). At high $\mathrm{T}$ and lower crustal conditions, especially in presence of $\mathrm{Na}$ and $\mathrm{Si}$ (Mysen, 2015 and references therein), HFSE, $U$ and Th can be transported in $\mathrm{H}_{2} \mathrm{O}$-rich fluids and subsequently transferred into the melt (Borghini et al., 2020). The melt shows a high concentration of $\operatorname{Zr}(1400 \mathrm{ppm}$ average), twice the expected amount ( 690 ppm) based on zircon solubility (Boehnke et al., 2013) 
at the corresponding temperature and inferred major-element melt composition. Inclusions of zircon (typical host of $\mathrm{Zr}$ and $\mathrm{Hf}$ ) are very rare in Gore Mountain $\mathrm{MI}$, and zircon-bearing inclusions were carefully avoided during analyses. This suggests that both $\mathrm{Zr}$ and $\mathrm{Hf}$ enrichments are features of the melt itself, likely related to the increase in HFSE solubility in the presence of a free fluid (Bartels et al., 2010). $\mathrm{Nb}$ and Ta should be equally transported in the kind of fluid discussed here, but they are yet not as enriched as $\mathrm{Zr}$-HfTh-U in the melt inclusions. This could be due to the growth of ilmenite (and possibly even rutile), observed as mineral inclusions in garnet, during metamorphism and melting and likely to contain a sizable amount of $\mathrm{Nb}$ and $\mathrm{Ta}$.

In presence of an infiltrating fluid, the melt would be furthermore expected to be enriched in Large Ion Lithophile Elements (LILEs), incompatible components generally partitioned in fluids (Cannaó and Malaspina, 2018). However, in our case study LILE and HFSE appear to be decoupled, i.e., the melt shows no particular enrichment in Cs, Rb, $\mathrm{Ba}$ and $\mathrm{Sr}$ relative to the host gabbro (Fig. 4b). This may suggest a LILE-poor source, e.g. possibly related to the mantle rather than to the crust. Finally, also the $\mathrm{H}_{2} \mathrm{O}$-rich nature of the fluid itself is unexpected in the lower portion of an orogen undergoing collapse at the time of garnet megacrysts formation (1050 Ma; see McLelland and Selleck, 2011). The enigma represented by the fluid origin requires further studies, currently underway and involving stable isotopes investigation (Ferrero et al., in preparation).

Although the presence of a free fluid during melting of the mafic lower crust (at $P \geq$ $1.0 \mathrm{GPa}$ ) was not regarded as a common situation (Moyen and Martin, 2012), this has been recently proposed to explain the origin of arc granitoids and the continental crust in general (Collins et al., 2020; Pourteau et al., 2020). In the case of Gore Mountain, 
Goldblum and Hill (1992) suggested that the high ductility contrast between the original gabbro and the surrounding metasyenites caused the formation of a shear zone (Fig. 1b), which acted as preferential pathway for the ingress of fluid at depth.

In summary, we propose that the olivine gabbro, prior to fluid infiltration, resided in the lower part of the orogen at $\mathrm{T}$ in excess of $900^{\circ} \mathrm{C}$ without undergoing melting because of its very dry composition $\left(0.44 \mathrm{wt} \% \mathrm{H}_{2} \mathrm{O}\right.$, McLelland and Selleck, 2011) and elevated solidus temperature, e.g. $>1000^{\circ} \mathrm{C}$ for this $\mathrm{H}_{2} \mathrm{O}$ content (dashed line in Fig. 5a). The infiltration of a $\mathrm{H}_{2} \mathrm{O}$-rich fluid decreased significantly the solidus of the gabbro assemblage, allowing its mineral components to undergo melting, as a response to the change in $\mathrm{H}_{2} \mathrm{O}$ content in the system. This may have taken place either at the same PT conditions present before melting or during an increase of both $\mathrm{P}$ and $\mathrm{T}$, as recently proposed by Shinevar et al. (2021).

\subsection{Nanotrondhjemites, experimental melts and natural TTGs}

The trondhjemitic melt enclosed in the nanogranitoids of Gore Mountain is hydrous, peraluminous and with very low maficity (Table 1). The high ASI of the melt preserved at Gore Mountain cannot be ascribed to interaction with the host garnet, as evidence of chemical interaction, either chemical zoning in the garnet surrounding the rehomogenized inclusions or embayments in the inclusion walls (see paragraph 4.2), are completely absent in the analyzed inclusions. The peraluminous character is consistent with the presence of osumilite as minor daughter phase in the inclusions: this phase is a rare alumina-rich, double-ring silicate found both in igneous and metamorphic UHT rocks (Kelsey, 2008). An oddity is however the presence of amphibole as daughter mineral in 
the inclusions: these phases are indeed more common in metaluminous rather than peraluminous melts (Bonin et al., 2020 and references therein), and this remains an enigmatic aspect of these nanotrondhjemites.

Nanogranitoids are natural capsules where melt is trapped immediately after production and then preserved (Cesare et al., 2015), making them directly comparable to melts from mafic melting experiments in presence of $\mathrm{H}_{2} \mathrm{O}$ (Fig. 7). The re-homogenized inclusions plot in the granitic field of the total alkali versus silica (TAS) diagram (Fig. 7a), near the most silica-rich experimental melts (e.g., Laurie and Stevens, 2012). The inclusions show a range of $\mathrm{Na}_{2} \mathrm{O}$ values consistent with the experimental dataset on mafic melting, whereas both $\mathrm{CaO}$ (Fig. 7b) and $\mathrm{Al}_{2} \mathrm{O}_{3}$ (Fig. 7c) are generally lower than the majority of the experimental melts, in agreement with the trondhjemitic nature of the inclusions (see also the Ab-Or-An ternary diagram, Fig. 7d). In general, the trapped melt appears to be lower in alkalis than most experimental melts even after alkali-correction, a feature likely to contribute to the high ASI displayed by these melts (Fig. 8a), despite the generally low Al content of the inclusions (Figs. 8b; 7c). Moreover, the investigated nanotrondhjemites appear to represent the low-calcium, low-alumina "end-member" of the positive trend defined by the cloud of experimental melts (Fig. 8b). The observed chemical differences could be explained by slightly different starting compositions. The Gore Mountain gabbro has a peculiar composition and is notably more mafic and showing higher $\mathrm{Al} / \mathrm{Ca}$ ratio than all the starting materials from mafic melting experiments compiled here (1.13 vs. $0.63-1.01$; all values are reported in Supplementary Table S4). In fact, as part of an anorthosite suite (McLelland and Selleck, 2011), it somewhat differs in composition from expected sources for TTGs that are rather tholeiitic to transitional 
basalts / amphibolites (Moyen and Martin, 2012). Despite these differences, the range of ASI values found in the nanotrondhjemites is fully comparable to the experimental melts (Fig. 8a), indicating that the $\mathrm{Al}_{2} \mathrm{O}_{3}, \mathrm{CaO}, \mathrm{Na}_{2} \mathrm{O}$ and $\mathrm{K}_{2} \mathrm{O}$ balance is consistent with phase relations characterizing the melting of mafic rocks.

When compared to natural TTGs, the Gore Mountain MI display higher ASI and similar Al (Fig. 8c) and both lower Ca and Al (Fig. 8d). A discrepancy is however not unexpected: as mentioned above, the source composition of the Gore Mountain MI might not be a perfect match to that of TTG magmas. In addition, these nanogranitoids contain a pristine melt trapped directly at the source region, making them necessarily different from TTG plutons/complexes, whose compositional diversity results from processes occurring in the source, during magma ascent and during emplacement. Specifically, several (non-mutually exclusive) processes may explain the observed mismatch:

- differences in melting temperatures / melt fraction and thereby melt composition - with the silicic, Ca- and Al-poor Gore Mountain MI representing an incipient stage of partial melting, whereas higher melt fractions would be required for the formation of voluminous TTG plutons;

- entrainment of residual or peritectic material, which is recognized to increase the compositional scatter of crustal melts with respect to their starting composition measured in nanogranitoids from more felsic rocks (Bartoli et al, 2016);

- magma differentiation (Smithies et al., 2019) and crystal-liquid separation during emplacement in the upper crust (Laurent et al., 2020).

In fact, the Ca vs. Al compositional variability of natural TTGs is well encompassed by considering any, or a combination of these possibilities: further melting involving the 
breakdown of plagioclase, amphibole \pm orthopyroxene, or mixing in various proportions between a liquid similar to the Gore Mountain inclusions and any combination of peritectic, residual or daughter minerals (Fig. 8d). In this perspective, the Gore Mountain MI are "embryos" (Bartoli et al., 2014) of TTGs, in the same way that nanogranitoids in silica-rich crustal rocks are embryos of S-type granites (Bartoli et al., 2016).

\subsection{Implications for TTG petrogenesis}

Although the composition of the Gore Mountain and natural TTGs may not be directly comparable in details, both bear a typical geochemical signature resulting from melting of K-poor mafic rocks, i.e., their silica-rich, trondhjemitic signature. Therefore, both can be discussed together to better constrain such melting processes, relevant to the generation of the Earth's earliest continental crust. In studies based on natural samples, this signature is interpreted to result from melting at $P \geq 2.0 \mathrm{GPa}$ in equilibrium with garnet and rutile, defining the so-called "High-Pressure" TTG (HP-TTG) group (Moyen, 2011). Thermodynamic modelling on Archean mafic rocks have recently shown that HP-TTGs may form at $900-950^{\circ} \mathrm{C}$ and lower P, i.e. 1.3-1.8 GPa (Kendrick and Yakymchuk, 2020) and down to 1.2 GPa (Johnson et al., 2017). Our finding shows that it is possible to form trondhjemitic melts with broadly comparable major elements signatures with HP-TTGs at similar $\mathrm{T}\left(\geq 925^{\circ} \mathrm{C}\right)$ and $\mathrm{P}$ conditions $(1.0 \mathrm{GPa})$, directly from melting of lower crustal mafic rocks. Moreover, the Gore Mountain garnet amphibolite displays all the mineralogical hallmarks characteristic of residues of "low-pressure" (LP-) TTGs (i.e. formed at $<1.2$ GPa, Moyen, 2011): amphibole and plagioclase are abundant, and orthopyroxene is present instead of clinopyroxene. This apparent discrepancy between melt and residual 
compositions may result from a significantly different melting process than generally assumed. Although the source system is dominated by LP assemblages, the liquid itself is in equilibrium with a solid assemblage containing phases more characteristic of much deeper melting, i.e. garnet and rutile. This reflects the incongruent melting of mafic rocks, with garnet and rutile production as melting initiates, whereas this has been regarded so far in TTG petrogenesis as a mainly eutectic process, with garnet and other components of the residue being already present before the initiation of melting, and then in excess during melting (Moyen and Martin, 2012). However, the absence of relicts of sub-solidus portions in the garnet megacrysts, i.e., a clear prograde zoning, despite its pluridecimetric size supports the evidence that these porphyroblasts started growing only at the onset of the melting, similarly to what was observed in experiments on mafic rocks (Beard and Lofgren, 1991) and other systems (Patiño Douce and Harris, 1998).

Conversely, the trace element concentrations of Gore Mountain Ml show contrasting LP-like and HP-like features. Sr and LREE contents are fully compatible with LP-TTGs (Fig. 9a), whereas Nb and Ta are very low, as typically ascribed to HP-TTGs (Fig. 9b, c) due to the presence of rutile and ilmenite as well as amphibole (for $\mathrm{Nb}$ ) in the residue. Thermodynamic calculations on Archean basalts (Johnson et al., 2017) have shown that TTGs with garnet + rutile residue may indeed form at P as low as $1.2 \mathrm{GPa}$, typical of LPTTGs, thus supporting the idea that LP melts from mafic melting can share features with HP-TTGs. This requires a careful re-evaluation of the existent databases, insofar as some TTGs currently classified as HP-TTGs based on Nb and Ta contents should be instead classified as LP-TTGs. 


\section{Conclusions}

The garnet megacrysts of Barton mine at Gore Mountain have been attracting the attention of expert scientific audience and general public alike since their discovery in the 1850's (Kelly and Darling, 2008) because of their unparalleled size. This feature swayed the attention of most of the scientific community toward the macroscale features of these crystals, at the expenses of high-resolution studies in the garnet interiors (with the remarkable exception of Shinevar et al. 2021). Our work shows how novel insights into geological processes with both local and worldwide relevance can be gained from the study of the microstructural features of such rocks. Our petrographic, experimental and modelling results prove for the first time that these garnets are peritectic and preserve micrometric droplets of trondhjemitic melt. Such melt results from the $\mathrm{H}_{2} \mathrm{O}$-fluxed melting of a gabbro in the lower crust during ultrahigh temperature metamorphism, a condition only recently recognized in the Adirondack Highlands (Shinevar et al., 2021) and still controversial. Further studies are needed to relate our solid microstructural and microchemical constraints to the geodynamic evolution of the area during the late Mesoproterozoic.

The compositional similarity between the trondhjemitic MI and TTGs provides us with the possibility to directly investigate the composition of the trondhjemitic melt, the phases coexistent with it as well as its mafic source rock, generated under wellconstrained conditions. Our work shows how $\mathrm{H}_{2} \mathrm{O}$-fluxed partial melting of mafic crust creates TTG-like melts with "HP-like" major elements and hybrid traces, i.e., "LP-like" in $\mathrm{Sr}$ and Ce contents and "HP-like" in Nb and Ta. Previously thought to be smoking guns of different melting P (at crustal versus mantle depths), such contrasting features within 
a single melt inclusion demonstrates that trace element signatures of TTGs are not diagnostic of depth of melting and geodynamic setting (see also Smithies et al., 2019). This result is complementary to recent findings that crystal-liquid segregation in TTG plutons can result in similar discrepancies (Laurent et al., 2020), pointing out that both source processes (melting reaction, $\mathrm{H}_{2} \mathrm{O}$ activity) and magma chamber dynamics exert a first-order control on TTG geochemistry, instead of melting pressure. Our finding provides support to the idea of a two-stage mechanism of TTG production (Moyen and Martin, 2012), i.e., mantle melting to produce basalt/gabbro, followed by melting of basalt/gabbro at lower crustal conditions to produce the TTG parental magma. This does not invalidate however other TTG production models, i.e. a one-stage mechanism whereby TTGs are produced by direct fractional crystallization of hydrous basalts (Jagoutz et al., 2013), which remain a valid explanation for occurrences where TTG granitoids are associated with magmatic cumulates in the lower crust.

In conclusion, these TTG embryos are a direct natural evidence that melting of mafic rocks generates TTG-like melts, in agreement with previous research (e.g., Jonhson et al., 2012; Porteau et al., 2020), and that such melts can be found in the source region as MI. It is arguable that the production of TTG-like melts at Gore Mountain is the result of a peculiar set of circumstance of local significance, i.e., local $\mathrm{H}_{2} \mathrm{O}$-rich fluid infiltration at depth. Nevertheless, $\mathrm{H}_{2} \mathrm{O}$-fluxed melting of lower crustal mafic rocks is increasingly recognized as a fundamental process for the production of TTGs, thus lending to our findings a clear and undoubtable relevance for the advancement of our understanding of TTG petrogenesis. 


\section{Acknowledgements}

Our deepest thanks go to Bonnie Barton for being an outstanding guide during our visit to Barton Mines. The present research was funded by the German Federal Ministry for Education and Research and the Deutsche Forschungsgemeinschaft (Project FE 1527/22) to SF. We are grateful to C. Günter, M.A. Ziemann, F. Wilke, F. Kaufmann and L. Hecht for help during analyses and to C. Fischer for sample preparation. The comments of $\mathrm{T}$. Tacchetto and other anonymous reviewers on an earlier (shorter) version, and of $\mathrm{O}$. Jagoutz and T. Johnson on the latest version led to an improvement in both clarity and significance of the present manuscript.

\section{References}

Bartels, A., Holtz, F., and Linnen, R. L., 2010, Solubility of manganotantalite and manganocolumbite in pegmatitic melts: American Mineralogist, v. 95 (4), p. 537544, https://doi.org/10.2138/am.2010.3157.

Bartoli, O., Cesare, B., Poli, S., Acosta-Vigil, A., Esposito, R., Turina, A., Bodnar, R. J., Angel, R. J., and Hunter, J., 2013, Nanogranite inclusions in migmatitic garnet: behavior during piston-cylinder remelting experiments: Geofluids, 13, p. 405-420, https://doi.org/10.1111/gfl.12038.

Bartoli, O., Cesare, B., Remusat, L., Acosta-Vigil, A., and Poli, S, 2014, The $\mathrm{H}_{2} \mathrm{O}$ content of granite embryos: Earth and Planetary Science Letters, v. 395, p. 281290, https://doi.org/10.1016/j.epsl.2014.03.031.

Bartoli, O., Acosta-Vigil, A., Ferrero, S., and Cesare, B., 2016, Granitoid magmas preserved as melt inclusions in high-grade metamorphic rocks: American 
Mineralogist, $\quad$ v. $101, \quad$ p. $1543-1559$, https://doi.org/10.2138/am-2016$5541 C C B Y N C N D$.

Bartoli, O., and Cesare, B., 2020. Nanorocks: a 10 year old story: Rendiconti Lincei. Scienze Fisiche e Naturali, v. 31, p. 249-257, https://doi.org/10.1007/s12210-02000898-7.

Baxter, E. F., Caddick, M. J., and Ague, J. J., 2013, Garnet: Common mineral, uncommonly useful. Elements, v. 9(6), p. 415-419.

Beard, J. S., and Lofgren, G. E., 1991, Dehydration melting and water-saturated melting of basaltic and andesitic greenstones and amphibolites at 1, 3, and 6. 9 kb: Journal of Petrology, v. 32, p. 365-401, https://doi.org/10.1093/petrology/32.2.365.

Boehnke, P., Watson, B. E., Trail, D., Harrison, T. M., and Schmitt, A. K., 2013, Zircon saturation re-revisited: Chemical Geology, v. 351, p. 324-334, https://doi.org/10.1016/j.chemgeo.2013.05.028.

Bonin, B., Janoušek, V., and Moyen, J.-F:, 2020, Chemical variation, modal composition and classification pf granitoids, in Janoušek, V., Bonin, B., Collins, W.J., Farina, F., and Bowden, P., eds., Post-Archean Granitic Rocks: Petrogenetic Processes and Tectonic Environments: Geological Society, London, Special Publications, v. 491, p. 9-51, https://doi.org/10.1144/SP491-2019-138.

Borghini, A., Ferrero, S., O’Brien, P. J., Laurent, O., Günter, C., and Ziemann, M. A., 2020, Cryptic metasomatic agent measured in situ in Variscan mantle rocks: Melt 
inclusions in garnet of eclogite, Granulitgebirge, Germany: Journal of Metamorphic Geology, v. 38, p. 207-234, https://doi.org/10.1111/jmg.12519.

Brown, C. R., Yakymchuk, C., Brown, M., Fanning, C. M., Korhonen, F. J., Piccoli, P. M., and Siddoway, 2016, From Source to Sink: Petrogenesis of Cretaceous Anatectic Granites from the Fosdick Migmatite - Granite Complex, West Antarctica: Journal of Petrology, v. 57 (7), p. 1241-1278, https://doi.org/10.1093/petrology/egw039.

Cannaó, E., and Malaspina, N., 2018, From oceanic to continental subduction: Implications for the geochemical and redox evolution of the supra-subduction mantle: Geosphere, v. 14, no. 6, p. 2311-2336, https:// doi .org /10 .1130 /GES01597.1.

Cesare, B., Acosta-Vigil, A., Bartoli, O., and Ferrero, S., 2015, What can we learn from melt inclusions in migmatites and granulites? Lithos, v. 239, p. 186-216, https://doi.org/10.1016/j.lithos.2015.09.028.

Collins, W. J., Murphy, J. B., Johnson, T. E., and Huang, H.-Q., 2020, Critical role of water in the formation of continental crust: Nature Geoscience, v. 13, p. 331-338, https://doi.org/10.1038/s41561-020-0573-6.

Darling, R. S., 2013, Zircon-bearing, crystallized melt inclusions in peritectic garnet from the western Adirondack Mountains, New York State, USA: Geofluids, v. 13 (4), p. 453-459, https://doi.org/10.1111/gfl.12047. 
Darling, R. S., Chou, I.-M., and Bodnar, R. J., 1997, An occurrence of metastable cristobalite in high-pressure garnet granulite: Science, v. 276, p. 91-93, https://doi.org/10.1126/science.276.5309.91.

Darling, R.S. and Peck, W.H., 2016, Metamorphic conditions of Adirondack rocks: Adirondack Journal of Environmental Studies, v. 21, Article 7.

Davis, M., Leech, M. and Metzger, E.P., 2020, Determining the Petrotectonic Evolution of Ledge Mountain Migmatites with Phase Equilibria Modelling and Melt Reintegration: Adirondack Highlands, New York. Abstract V019-0004 presented at 2020 Fall Meeting, AGU, San Francisco, CA, 1-17 Dec.

Ferrero, S., and Angel, R. J., 2018, Micropetrology: are inclusions in minerals grains of truth? Journal of Petrology, v. 59, p. 1671-1700, doi: 10.1093/petrology/egy075.

Ferrero, S., O’Brien, P. J., Borghini, A., Wunder, B., Wälle, M., Günter, C., and Ziemann, M. A., 2018, A treasure chest full of nanogranitoids: an archive to investigate crustal melting in the Bohemian Massif, in Ferrero, S., Lanari, P., Goncalves, P., and Grosch, E. G., eds., Metamorphic Geology: Microscale to Mountain Belts: Geological Society, London, Special Publications 478, p. 13-38, https://doi.org/10.1144/SP478.19.

Ferrero, S., Ague, J.J., O’Brien, P.J., Wunder, B., Remusat, L., Ziemann, M.A., Axler, J., 2021, High pressure, halogen-bearing melt preserved in ultra-high temperature felsic granulites of the Central Maine Terrane, Connecticut (US): American Mineralogist, in press, https://doi.org/10.2138/am-2021-7690. 
Forshaw, J. B., Waters, D. J., Pattison, D. R. M., Pallin, R., and Gopon, P., 2019, A comparison of observed and thermodynamically predicted phase equilibria and mineral compositions in mafic granulites: Journal of Metamorphic Geology, v. 37, p. 153-179, https://doi.org/10.1111/jmg.12454.

Goldblum, D. R., and Hill, M. L., 1992, Enhanced fluid flow resulting from competency contrast within a shear zone: The garnet ore zone at Gore Mountain, N.Y: The Journal of Geology, v. 100, p. 776-782, https://doi.org/10.1086/629628.

Hollocher, K., 2008, Origin of big garnets in amphibolites during high-grade metamorphism, Adirondacks, New York: $21^{\text {st }}$ Annual Keck Undergraduate Research Symposium, p. 129-134.

Jagoutz, O., Schmidt, M. W., Enggist, A., Burg, J.-P., Hamid, D., and Hussain, S., 2013, TTG-type plutonic rocks formed in a modern arc batholith by hydrous fractionation in the lower arc crust: Contributions to Mineralogy and Petrology, v. 166(4), p. 1099-1118, https://doi.org/10.1007/s00410-013-0911-4.

Johnson, T. E., Brown, M., Kaus, B. J. P., and VanTongeren, J. A., 2013, Delamination and recycling of Archaean crust caused by gravitational instabilities: Nature Geoscience, v. 7, p. 47-52, https://doi.org/10.1038/ngeo2019.

Johnson, T. E., Brown, M., Gardiner, N. J., Kirkland, C. L., and Smithies, R. H., 2017, Earth's first stable continents did not form by subduction: Nature, v. 543 , p. 239 242, https://doi.org/10.1038/nature21383. 
Johnson, T. E., Fischer, S., White, Brown, M., Rollinson, H.R., 2012, Archaean intracrustal differentiation from partial melting of metagabbro-field and geochemical evidence from the central region of the Lewisian complex, NW Scotland: Journal of Petrology, v. 53 (10), p. 2115-2138. https://doi.org/10.1093/petrology/egs046

Johnston, A. D., and Wyllie, P. J., 1988, Constraints on the origin of Archean trondhjemites based on phase relationships of Nûk gneiss with $\mathrm{H}_{2} \mathrm{O}$ at 15 kbar: Contributions to Mineralogy and Petrology, v. 100, p. 35-46, https://doi.org/10.1007/BF00399438.

Kelly, W.M., and Darling, R. S., 2008, Geology and mining history of the Barton garnet mine, Gore Mt., and the NL ilmenite mine, Tahawus, NY with a temporal excursion to the Macintyre, in Selleck, B.W., $80^{\text {th }}$ Annual Meeting of the New York State Geological Association, Fieldtrip Guidebook, 154 p.

Kelsey, D. E., 2008, On ultrahigh-temperature crustal metamorphism: Gondwana Research, v. 13 (1), p. 1-29, https://doi.org/10.1016/j.gr.2007.06.001.

Kendrick, J., and Yakymchuk, C., 2020, Garnet fractionation, progressive melt loss and bulk composition variations in anatectic metabasites: Complications for interpreting the geodynamic significance of TTGs: Geoscience Frontiers, v. 11, p. 745-763, https://doi.org/10.1016/j.gsf.2019.12.001.

Lanari, P. and Duesterhoeft, E., 2019, Modelling metamorphic rocks using equilibrium thermodynamics and internally consistent databases: past achievements, problems 
and perspectives: Journal of Petrology, 60(1), p.19-56, https://doi.org/10.1093/petrology/egy105.

Laurent, O., Björnsen, J., Wotzlaw, J.-F., Bretscher, S., Pimenta Silva, M., Moyen, J.F., Ulmer, P., and Bachmann, O., 2020, Earth's earliest granitoids are crystal-rich magma reservoirs tapped by silicic eruptions: Nature Geoscience, v. 13(2), p. 163169, https://doi.org/10.1038/s41561-019-0520-6.

Laurie, A., and Stevens, G., 2012, Water-present eclogite melting to produce Earth's early felsic crust: Chemical Geology, v. 314-317, p. 83-95, https://doi.org/10.1016/j.chemgeo.2012.05.001.

McLelland, J. M., and Selleck, B. W., 2011, Megacrystic Gore Mountain-type garnets in the Adirondack Highlands: Age, origin, and tectonic implications: Geosphere, v. 7, p. 1194-1208, https://doi.org/10.1130/GES00683.1.

Moyen, J.-F., 2011, The composite Archaean grey gneisses: Petrological significance, and evidence for a non-unique tectonic setting for Archaean crustal growth: Lithos, v. 123(1-4), p. 21-36, https://doi.org/10.1016/j.lithos.2010.09.015.

Moyen, J.-F., and Martin, H., 2012, Forty years of TTG research: Lithos, v. 148, p. 312-336, https://doi.org/10.1016/j.lithos.2012.06.010.

Mysen, B., 2015, An in situ experimental study of $\mathrm{Zr}^{4+}$ transport capacity of water-rich fluids in the temperature and pressure range of the deep crust and upper mantle: Progress in Earth and Planetary Science, v. 2, 38, https://doi.org/10.1186/s40645015-0070-5. 
Nicoli, G., and Ferrero, S., 2021, Nanorocks, volatiles and plate tectonics: Geoscience Frontiers, v. $12(5), 101188$.

Patiño Douce, A. E., and Harris, N., 1998, Experimental constraints on Himalayan anataxis: Journal of Petrology, v. 39(4), p. 689-710, https://doi.org/10.1093/petroj/39.4.689.

Pourteau, A., Ducet, L. S., Blereau, E. R., Volante, S., Johnson, T. E., Collins, W. J., Li, Z.-X., and Champion, D. C., 2020, TTG generation by fluid-fluxed crustal melting: Direct evidence from the Proterozoic Georgetown Inlier, NE Australia, v. 550, https://doi.org/10.1016/j.epsl.2020.116548.

Qian, Q., and Hermann, J., 2013, Partial melting of lower crust at 10-15 kbar: constraints on adakite and TTG formation: Contributions of Mineralogy and Petrology, v. 165, p. 1195-1224, https://doi.org/10.1007/s00410-013-0854-9.

Rivers, T., 1997, Lithotectonic elements of the Grenville Province: review and tectonic implications: Precambrian Research, v. 167, p. 117-154, https://doi.org/10.1016/S0301-9268(97)00038-7.

Shinevar, W.J., Jagoutz, O., and VanTongeren, J.A., 2021, Gore Mountain Garnet Amphibolite records UHT Conditions: Implications for the Rheology of the Lower Continental Crust During Orogenesis: Journal of Petrology, V. 62 (4), egab007, https://doi.org/10.1093/petrology/egab007.

Smithies, R. H., Lu, Y., Johnson, T., Kirkland, C. L., Cassidy, K. F., Champion, D. C., Mole, D. R., Zibra, I., Gessner, K., Sapkota, J., De Paoli, M. C., and Poujol, M., 
2019, No evidence for high-pressure melting of Earth's crust in the Archean: Nature Communications, v. 10, 5559, https://doi.org/10.1038/s41467-019-13547$\mathrm{x}$.

van der Laan, S. R., and Wyllie, P. J., 1992, Constraints on Archean Trondhjemite Genesis from Hydrous Crystallization Experiments on Nûk Gneiss at 10-17 kbar: The Journal of Geology, v. 100, p. 57-68.

White, R.W., Stevens, G. and Johnson, T.E., 2011. Is the crucible reproducible? Reconciling melting experiments with thermodynamic calculations. Elements, 7(4), p. 241-246.

Winther, T. K., 1996, An experimentally based model for the origin of tonalitic and trondhjemitic melts: Chemical Geology, v. 127, p. 43-59, https://doi.org/10.1016/0009-2541(95)00087-9.

Winther, T. K., and Newton, R. C., 1991, Experimental melting of a hydrous low-K tholeiite: evidence on the origin of Archaean cratons: Bulletin of the Geological Society of Denmark, v. 39. 


\section{Captions}

(a)
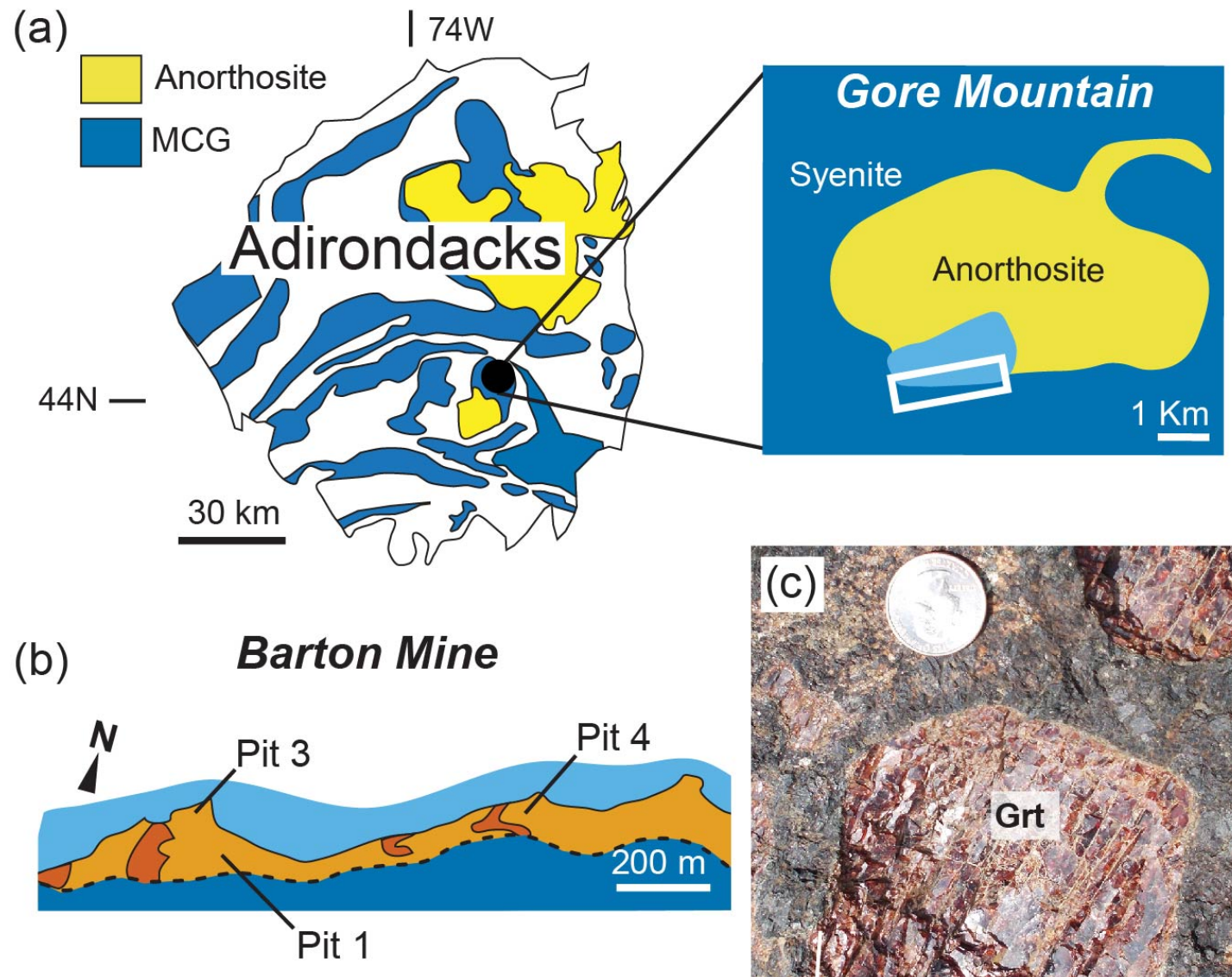

Garnet

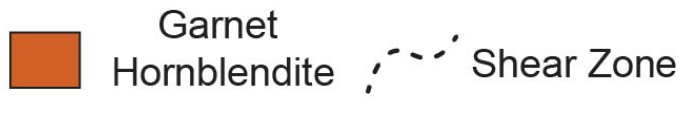

$\square \begin{gathered}\text { Garnet } \\ \text { Amphibolite } \square \quad \text { Gabbro }\end{gathered}$

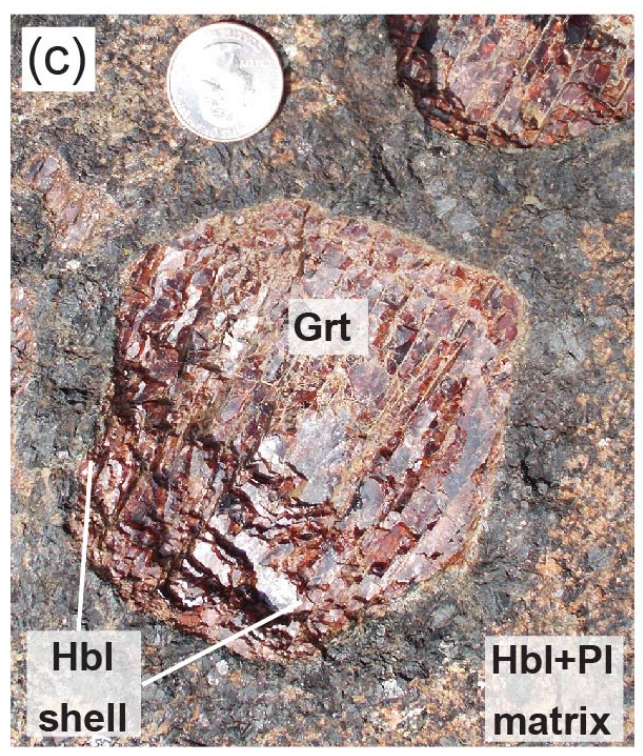

Fig. 1. a) Simplified geological setting (modified after McLelland and Selleck, 2011) of the Adirondacks (NY state, US) showing the rock types of interest. MCG= mangeritecharnockite-granite suite. Black dot= location of Gore Mountain, with general geologic setting in the inset on the right. White box= location of Barton Mine. (b) Detailed geological map of the open pit of Barton Mine. The inclusion-bearing garnets investigated in this study are from the garnet amphibolites; the garnet hornblendites present along with the amphibolites have smaller garnets hosted in a matrix of pluri-cm hornblende, and were 
not investigated in the present study. The location of the shear zone is based on Goldblum and Hill (1992). (c) Garnet (Grt) megacryst surrounded by hornblende (Hbl) in a matrix of $\mathrm{Hbl}$ and plagioclase $(\mathrm{Pl})$ and minor orthopyroxene, not visible in the figure. Coin diameter= $2.5 \mathrm{~cm}$. 

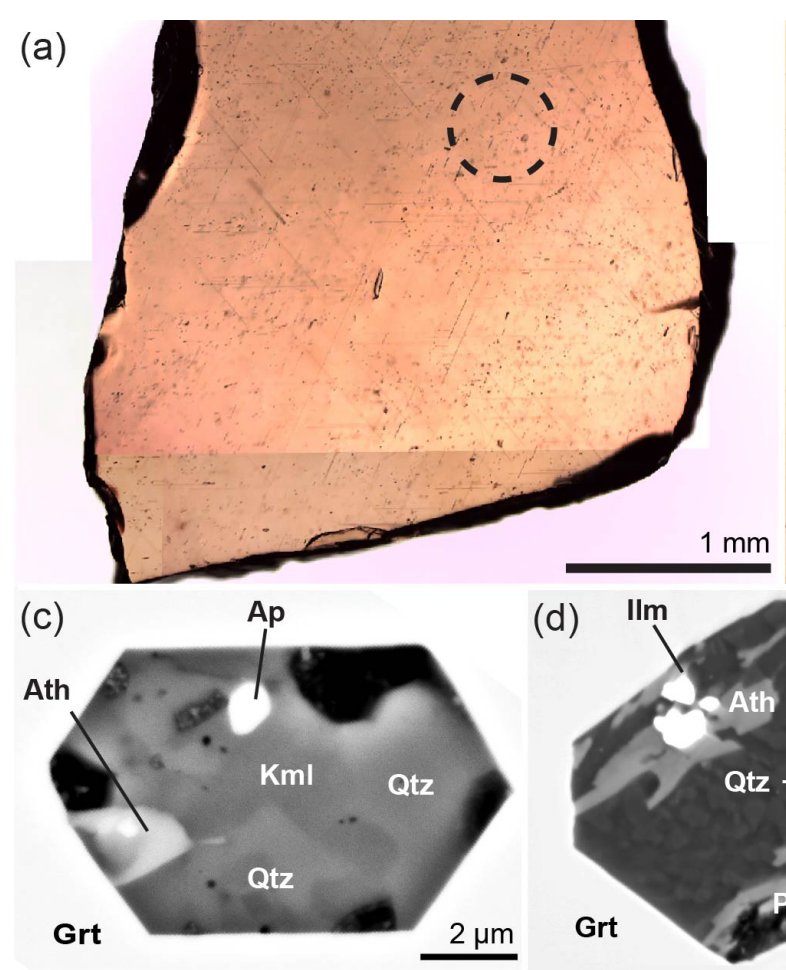

(f) (d)

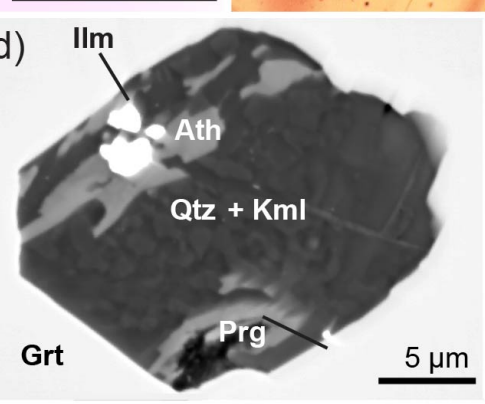

(b)

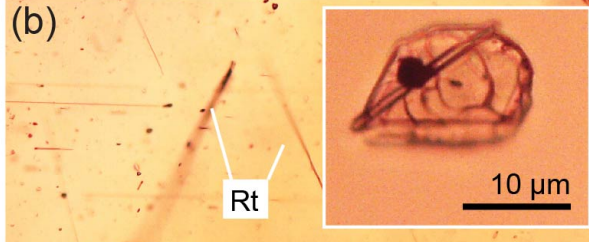

$\mu \mathrm{m}$

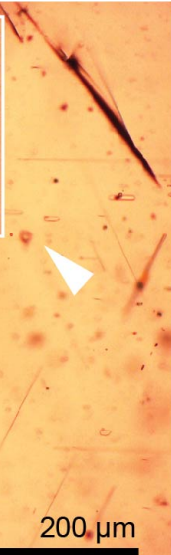

(e)

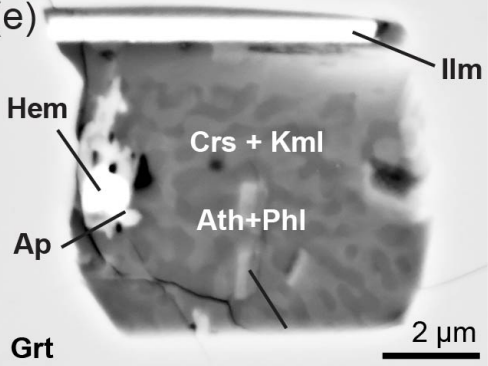

Raman spectra $\left(\mathrm{cm}^{-1}\right)$

Cristobalite

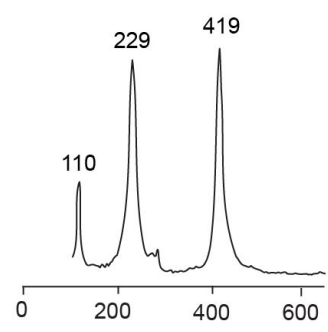

Kumdykolite

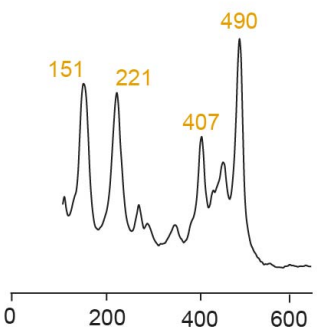

Pargasite

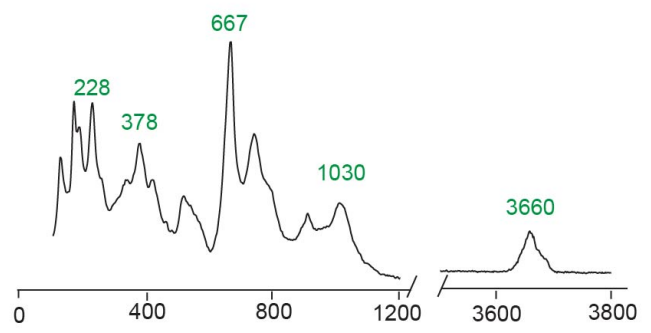

(g)

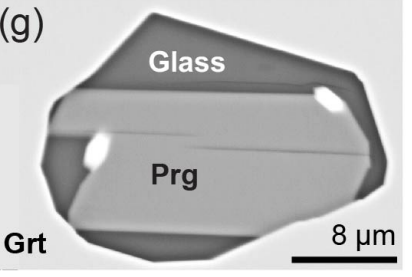

Residual Glass, Garnet
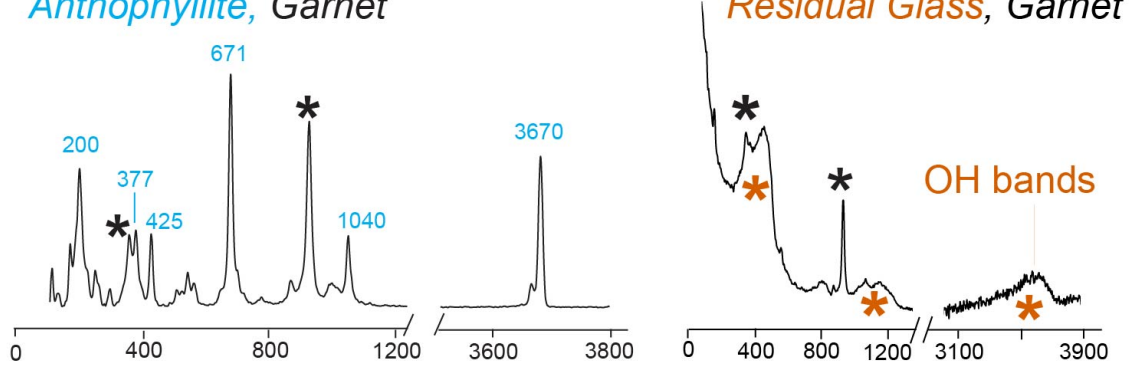

Fig. 2. Crystallized and partially crystallized melt inclusions in Gore Mountain megacrysts.

(a) Inclusion-bearing, doubly-polished chips of garnet megacrysts. Dashed circle= 
location of fig. (b). (b) close up of the garnet chip with enlargements of isometric and tubular inclusions. $\mathrm{Rt}=$ rutile needles. $(\mathrm{c}),(\mathrm{d})$ and $(\mathrm{e})$ back scattered electron (BSE) images of the inclusions. Ath=anthophyllite, Kml=kumdykolite, Crs= Cristobalite; Qtz= quartz, $\mathrm{Ap}=$ apatite, IIm=ilmenite, $\mathrm{Prg}=$ pargasite, $\mathrm{Phl}=$ phlogopite and Hem=hematite. In (d) and (e) kumdykolite and quartz/cristobalite show a typically igneous micrographic texture. (f) MicroRaman spectra of the crystalline phases in inclusions as well as glass. (g) Partially crystallized inclusion with MicroRaman spectrum of the glass visible in (f). 


\begin{tabular}{|c|c|c|c|c|c|c|c|}
\hline (a) & & & xperin & al rur & & & \\
\hline$\stackrel{n}{\mathbb{N}}$ & $T\left({ }^{\circ} \mathrm{C}\right)$ & 900 & 925 & 940 & 940 & 940 & 950 \\
\hline$\underline{E}$ & $P(G P a)$ & 1.0 & 1.0 & 1.0 & 1.5 & 1.5 & 1.0 \\
\hline & $t(h)$ & 24 & 24 & 24 & 24 & 24 & 24 \\
\hline
\end{tabular}

\begin{tabular}{|c|c|c|c|c|c|c|}
\hline Re-melting & - & Limited & + & + & + & + \\
\hline$\frac{\text { N }}{5} \quad$ Re-hom. & - & $\mathrm{Ml}<2 \mu \mathrm{m}$ & + & + & + & + \\
\hline Cracks & - & Rare & Rare & + & Rare & + \\
\hline Interaction & - & - & - & - & - & + \\
\hline Name & GM3 & GM5 & GM7 & GM8 & GM9 & GM1 \\
\hline
\end{tabular}

(b)

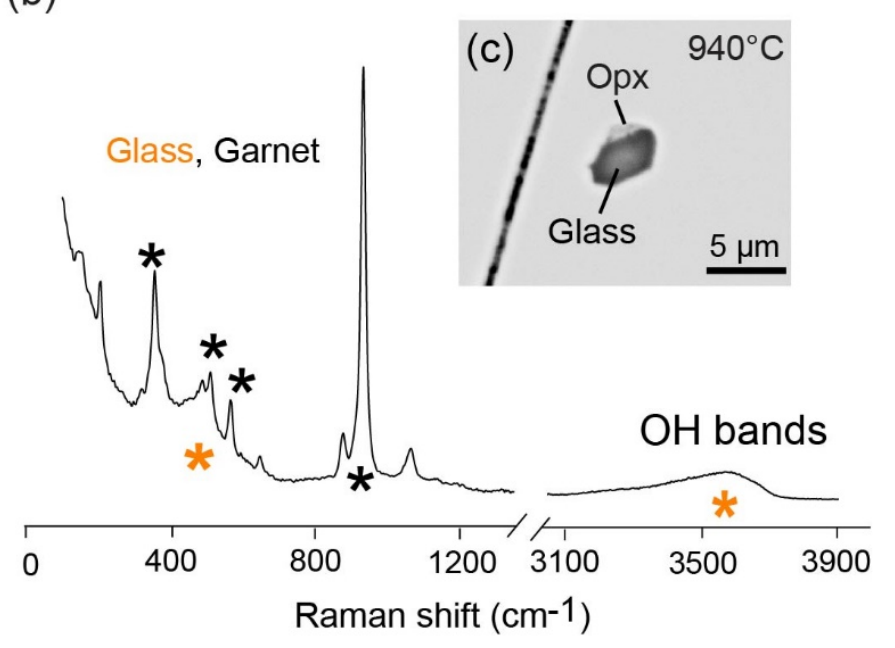

Fig. 3. Experimental re-homogenization of the inclusions. (a) Table reporting the parameters used in the re-homogenization experiments at the piston cylinder press, with relevant microstructural observations. In gray we report the two experiments where the inclusions were analyzed to obtain the composition of the original melt (Table 1). (b) Raman spectrum of the glass inside a fully re-homogenized nanogranitoid, visible in figure (c), next to an orthopyroxene interpreted as already coexisting with the melt during garnet growth and inclusion formation (see text for details). 


\begin{tabular}{|c|c|c|c|c|c|c|c|c|c|c|}
\hline Experiment & GM7 & GM7 & GM9 & GM9 & GM9 & GM9 & GM9 & & & \\
\hline No. & 28 & 25 & $32-32$ & 33 & 24 & 31 & $22-23$ & Average & St.Dev & $\begin{array}{r}\text { Residual } \\
\text { Glass }\end{array}$ \\
\hline $\begin{array}{r}\text { Trapped } \\
\text { phases }\end{array}$ & None & Opx & Opx & Opx & Opx & $\begin{array}{l}\text { Opx+Crs+l } \\
\text { Im }\end{array}$ & Opx & & & \\
\hline $\mathrm{SiO}_{2}$ & 69.70 & 71.79 & 75.81 & 73.79 & 72.04 & 72.30 & 67.79 & 71.89 & 2.06 & 77.58 \\
\hline $\mathrm{TiO}_{2}$ & 0.06 & 0.64 & 0.34 & 0.22 & 0.34 & 0.38 & 0.33 & 0.33 & 0.19 & 0.01 \\
\hline $\mathrm{Al}_{2} \mathrm{O}_{3}$ & 12.93 & 11.36 & 11.46 & 13.43 & 12.52 & 13.57 & 12.82 & 12.58 & 0.95 & 12.92 \\
\hline $\mathrm{FeO}$ & 3.54 & 4.47 & 2.43 & 4.84 & 3.51 & 2.59 & 2.91 & 3.47 & 0.97 & 0.80 \\
\hline $\mathrm{MnO}$ & 0.04 & 0.00 & 0.07 & 0.12 & 0.07 & 0.01 & 0.01 & 0.05 & 0.04 & 0.00 \\
\hline $\mathrm{MgO}$ & 1.72 & 2.54 & 0.50 & 1.62 & 1.70 & 1.00 & 0.72 & 1.40 & 0.70 & 0.06 \\
\hline $\mathrm{CaO}$ & 1.80 & 1.38 & 0.92 & 1.78 & 1.72 & 1.52 & 1.55 & 1.52 & 0.34 & 0.07 \\
\hline $\mathrm{Na}_{2} \mathrm{O}$ & 3.02 & 2.21 & 3.49 & 4.22 & 3.86 & 5.55 & 3.86 & 3.74 & 1.14 & 4.53 \\
\hline $\mathrm{K}_{2} \mathrm{O}$ & 1.34 & 0.44 & 0.31 & 0.25 & 0.38 & 0.20 & 1.81 & 0.67 & 0.43 & 3.25 \\
\hline $\mathrm{P}_{2} \mathrm{O}_{5}$ & 0.02 & 0.20 & 0.07 & 0.00 & 0.00 & 0.10 & 0.03 & 0.06 & 0.08 & 0.02 \\
\hline $\mathrm{Cl}$ & 0.00 & 0.00 & 0.03 & 0.02 & 0.00 & 0.00 & 0.26 & 0.05 & 0.01 & 0.00 \\
\hline Total & 94.18 & 95.02 & 95.43 & 100.29 & 96.12 & 97.22 & 92.09 & 95.77 & 2.17 & 99.25 \\
\hline$Q$ & 38 & 48 & 50 & 38 & 39 & 33 & 32 & 40 & 7 & 38 \\
\hline $\mathrm{C}$ & 3 & 5 & 4 & 3 & 3 & 2 & 2 & 3 & 1 & 2 \\
\hline Or & 8 & 3 & 2 & 1 & 2 & 1 & 11 & 4 & 4 & 19 \\
\hline$A b$ & 26 & 19 & 29 & 36 & 33 & 47 & 33 & 32 & 9 & 38 \\
\hline An & 9 & 6 & 4 & 9 & 9 & 7 & 7 & 7 & 2 & 0 \\
\hline $\mathrm{Hy}$ & 11 & 13 & 5 & 13 & 10 & 7 & 7 & 9 & 3 & 2 \\
\hline $\mathrm{Mg \#}$ & 0.46 & 0.50 & 0.26 & 0.37 & 0.46 & 0.41 & 0.30 & 0.39 & 0.09 & 0.11 \\
\hline ASI & 1.33 & 1.72 & 1.48 & 1.29 & 1.27 & 1.12 & 1.15 & 1.34 & 0.21 & 1.16 \\
\hline $\mathrm{Al}$ & 0.064 & 0.071 & 0.053 & 0.061 & 0.057 & 0.041 & 0.044 & 0.06 & 0.01 & 0.02 \\
\hline $\mathrm{Na}_{2} \mathrm{O} / \mathrm{CaO}$ & 0.44 & 0.20 & 0.09 & 0.06 & 0.10 & 0.04 & 0.47 & 0.20 & 0.17 & 0.72 \\
\hline $\mathrm{Al} / \mathrm{Na}+\mathrm{K}$ & 2.01 & 2.77 & 1.89 & 1.86 & 1.85 & 1.45 & 1.54 & 1.91 & 0.43 & 1.18 \\
\hline $\mathrm{K}_{2} \mathrm{O} / \mathrm{Na}_{2} \mathrm{O}$ & 1.68 & 1.60 & 3.78 & 2.37 & 2.25 & 3.65 & 2.48 & 2.54 & 0.87 & 68.0 \\
\hline maficity & 0.09 & 0.13 & 0.05 & 0.11 & 0.09 & 0.06 & 0.06 & 0.08 & 0.03 & 0.01 \\
\hline $\mathrm{H}_{2} \mathrm{O}$ by diff & 5.82 & 4.99 & 4.60 & -0.27 & 3.88 & 2.79 & 8.17 & 4.28 & 2.62 & 0.75 \\
\hline $\mathrm{K} \#$ & 0.23 & 0.12 & 0.06 & 0.04 & 0.06 & 0.02 & 0.24 & 0.11 & 0.09 & 0.32 \\
\hline
\end{tabular}

Table 1. Microchemical analyses of $\mathrm{MI}$ and residual glass. The Ml compositions were measured after experimental re-homogenization via EMP analyses. See "methods" for the alkali correction procedure. $\mathrm{Al}=\mathrm{Alkalinity}$ Index $(\mathrm{Al}=$ molar $\mathrm{Al}-(\mathrm{Na}+\mathrm{K}))$; maficity = total $\mathrm{FeO}$ and $\mathrm{MgO}$ contents expressed as atomic $\mathrm{Fe}+\mathrm{Mg}$; potassium number $(\mathrm{K \#})=[\mathrm{molar}$ $\left.\mathrm{K}_{2} \mathrm{O} /\left(\mathrm{K}_{2} \mathrm{O}+\mathrm{Na}_{2} \mathrm{O}\right)\right]$. Crs= cristobalite; Opx= Orthopyroxene. 

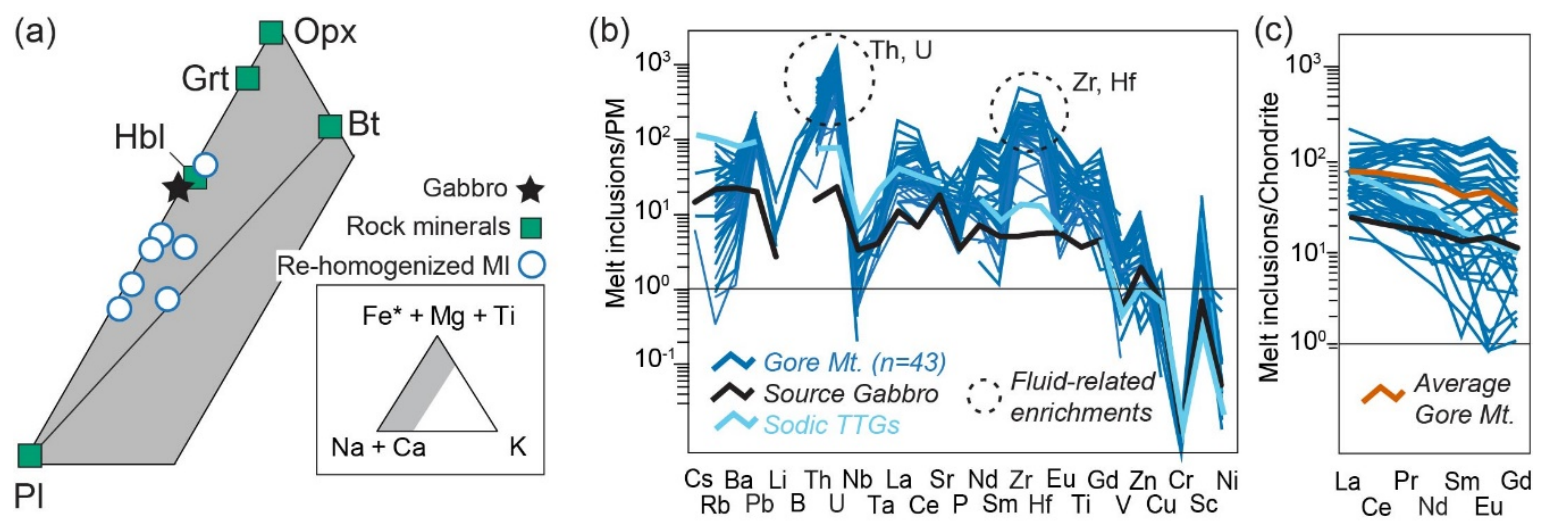

Fig. 4: Chemistry of the melt in inclusions. (a) Re-homogenized inclusion composition versus gabbro protolith (from McLelland and Selleck, 2011) and mineral phase composition in the garnet amphibolite. (b) Primitive mantle (PM)-normalized pattern of MI trace elements (Table S2) versus source rock and sodic TTGs average. (c) Chondritenormalized REE patterns of MI. Y and Heavy REE (HREE) contents of the Ml are not available due to limitations of the deconvolution (see Methods and text). The dataset does not include MI with trapped phases such as rutile, ilmenite, zircon and apatite. Sodic TTGs composition is from Moyen and Martin (2012). For details on "fluid-related enrichments" see section 4.4 . 
(a)

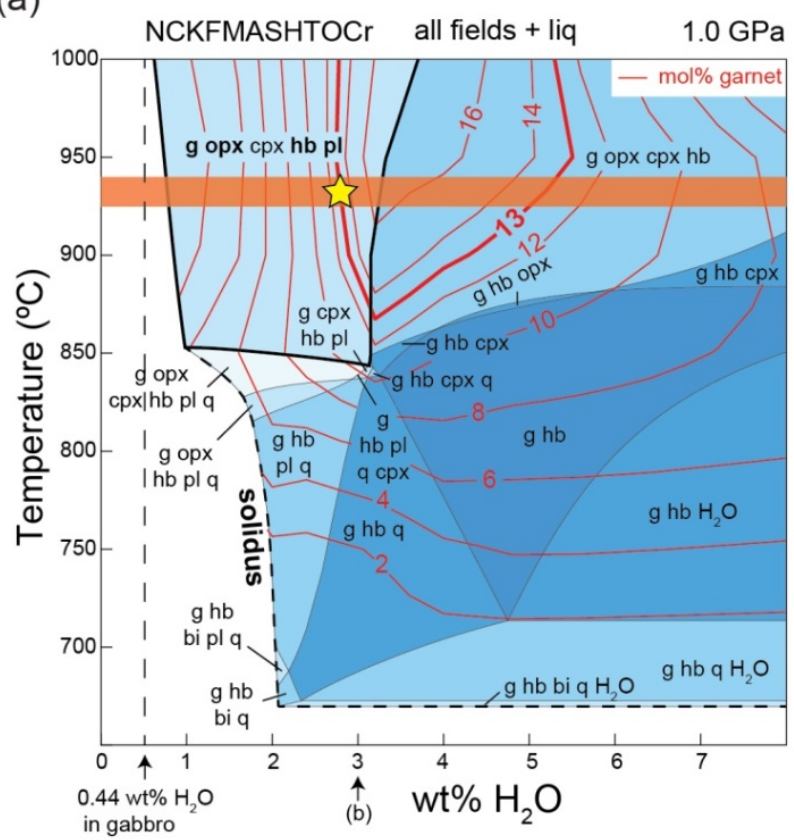

(b)

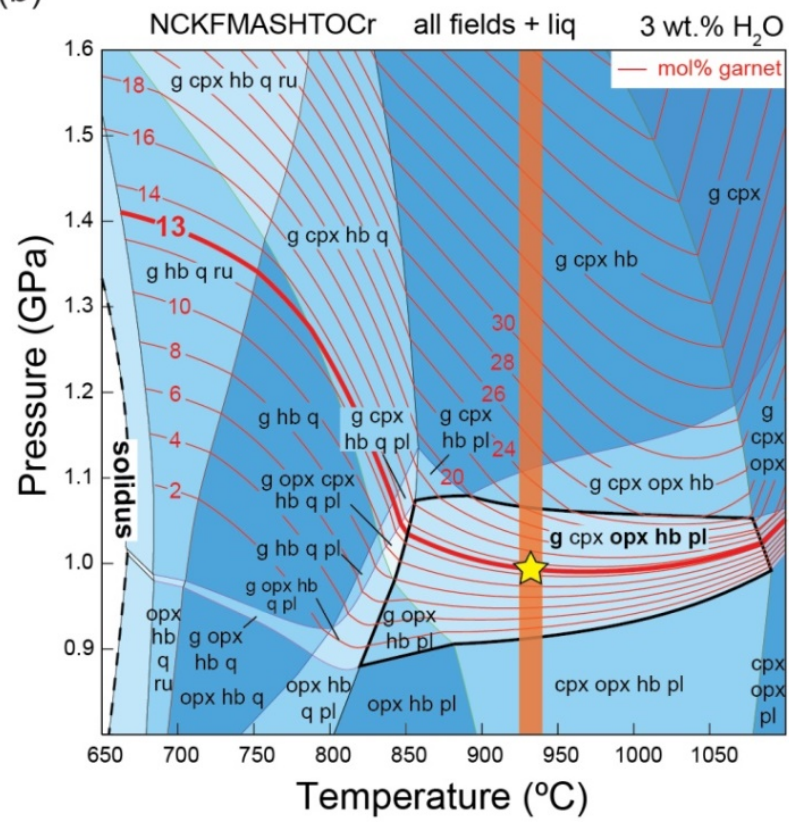

Fig. 5: Results of phase equilibrium modelling: (a) $\mathrm{T}-\mathrm{wt} \% \mathrm{H}_{2} \mathrm{O}$ diagram at $1.0 \mathrm{GPa}$, and (b) $P$-T diagram with $3 \mathrm{wt} \% \mathrm{H}_{2} \mathrm{O}$, also indicated in (a). Orange box $=\mathrm{T}$ range at which the inclusions can be successfully re-homogenized, $925-940^{\circ} \mathrm{C}$. Yellow star $=P T$ conditions 
of garnet megacrysts formation as result of melting, also corresponding to melt entrapment. 

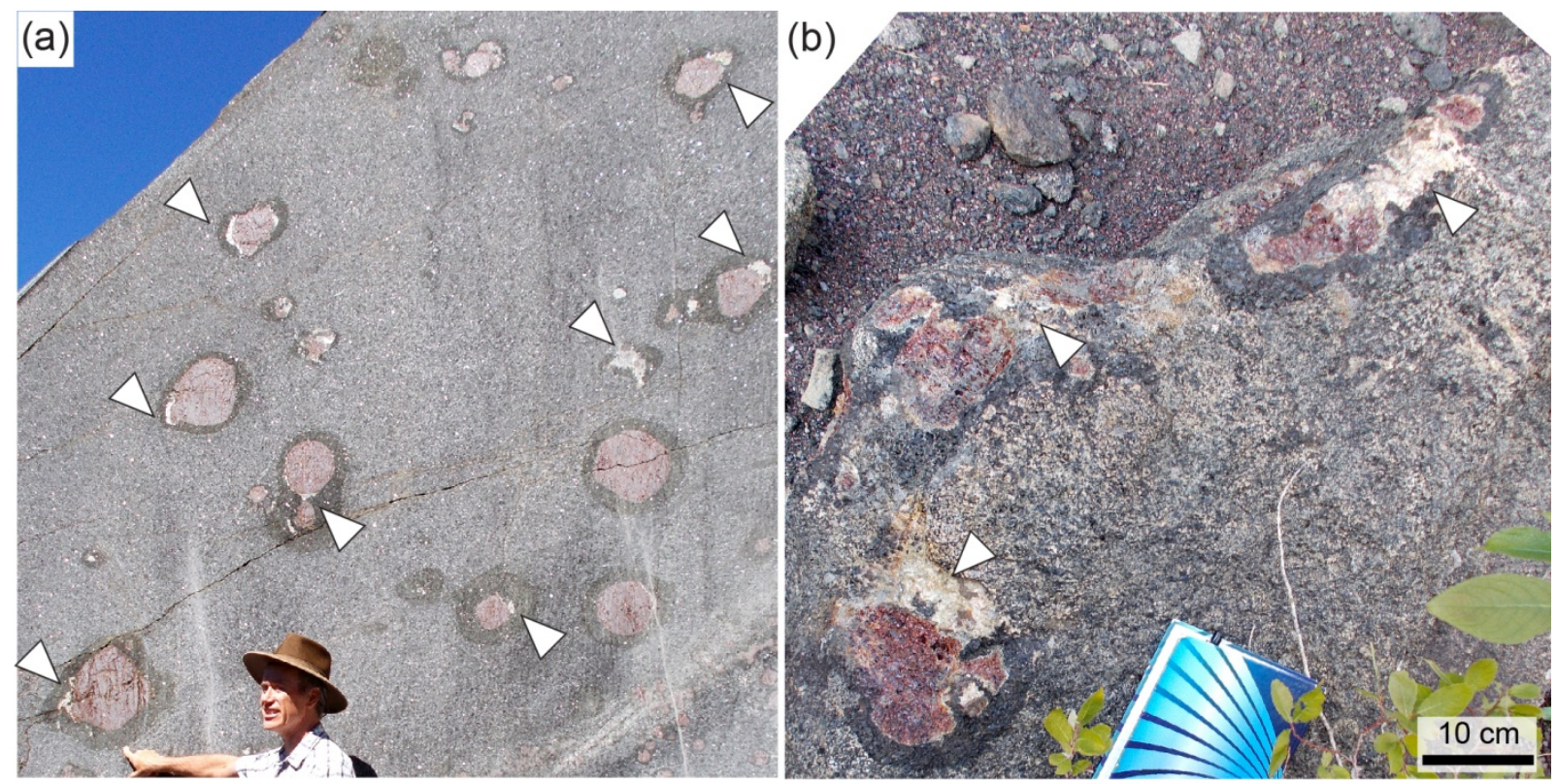

Fig. 6: Possible outcrop evidence for the former presence of melt. White arrows = leucocratic pockets. (a) Freshly cut surface (August 2018) located in pit 3 (. (b) Loose boulder in the lower part of pit 1. 

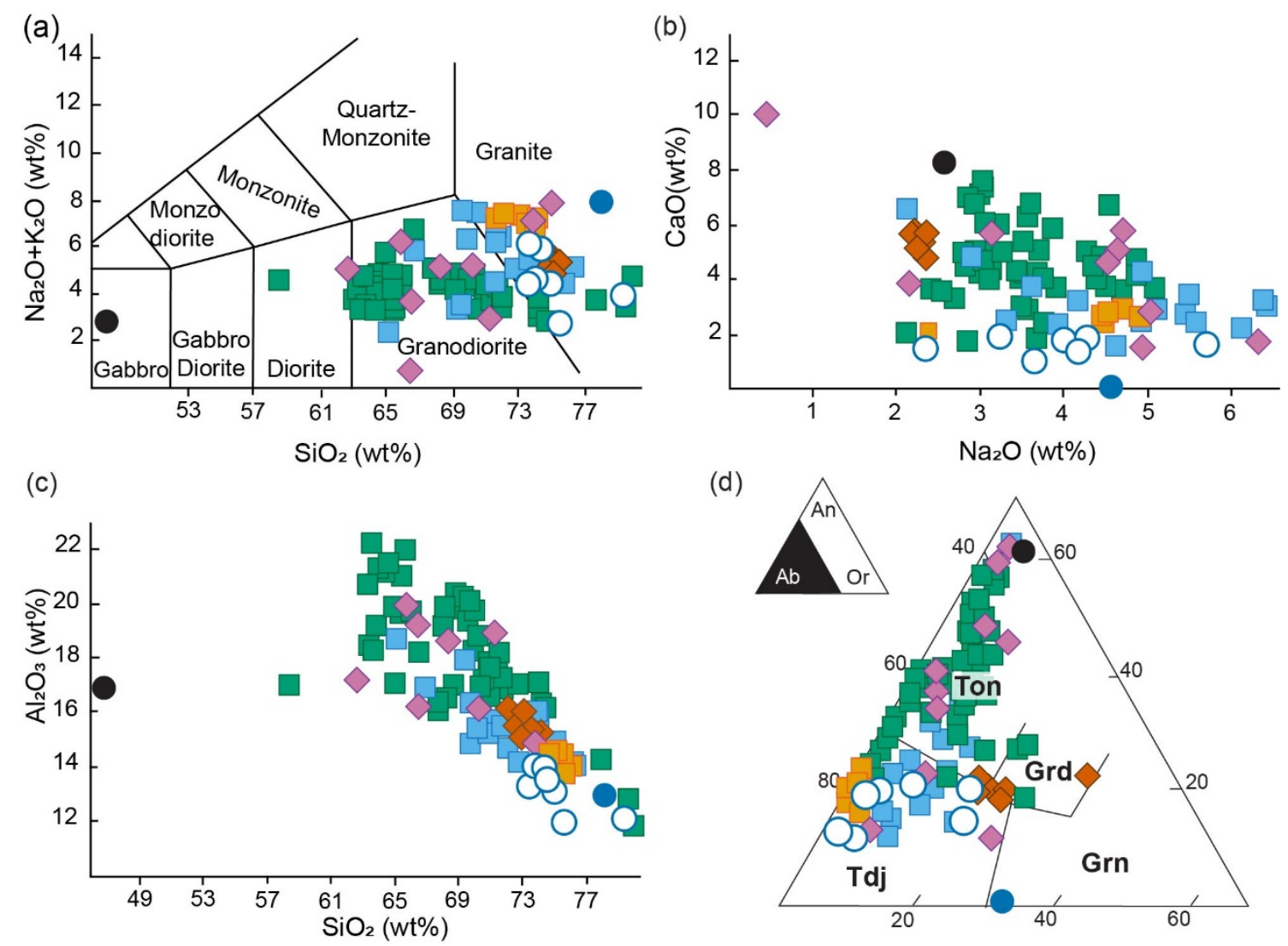

(d)

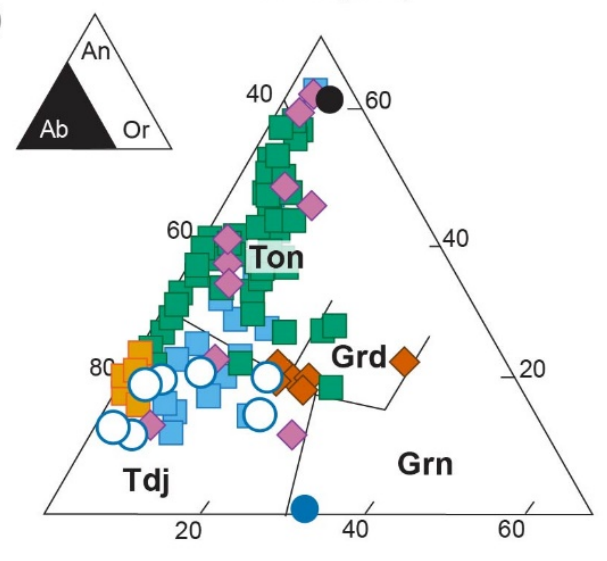

This study

Re-homogenized MI Residual glass

Gabbro Protolith

\section{Experimental melts}

Beard \& Lofgren 91 Johnston \& Wyllie 88 $\checkmark$ Winther \& Newton $91 \quad$ Laurie \& Stevens 12

Winther 96

Fig. 7: Comparison between chemical features of $\mathrm{MI}$ from this study and melts from experimental studies involving a mafic protolith re-melted in presence of $\mathrm{H}_{2} \mathrm{O}$. The entire dataset used in the figures is visible in Supplementary file Table S3. (a) TAS diagram, (b) $\mathrm{Na}_{2} \mathrm{O}$ vs $\mathrm{CaO}$ plot, (c) $\mathrm{SiO}_{2}$ vs $\mathrm{Al}_{2} \mathrm{O}_{3}$ plot and (d) Ab-Or-An ternary diagram. $\mathrm{Tdj}=$ trondhjemite, Ton = tonalite, Grd = granodiorite and Grn = granite . 
(a)

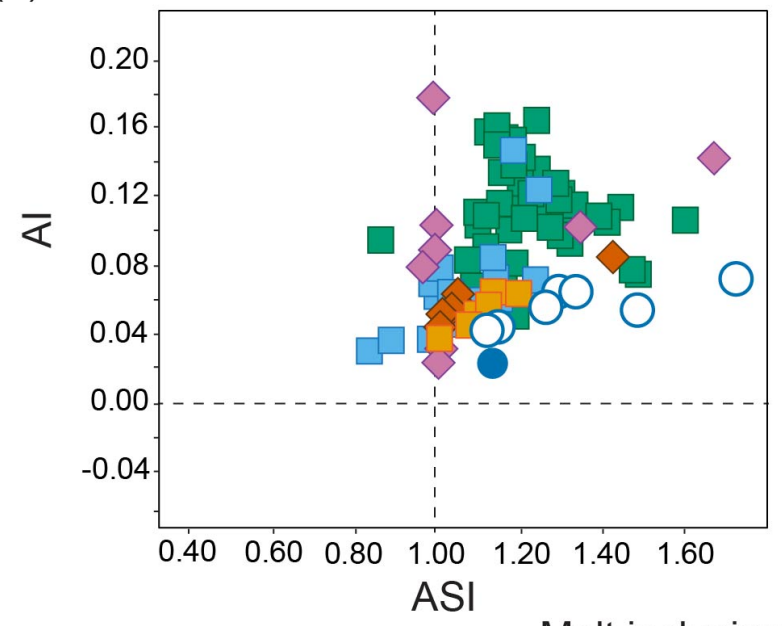

(b)

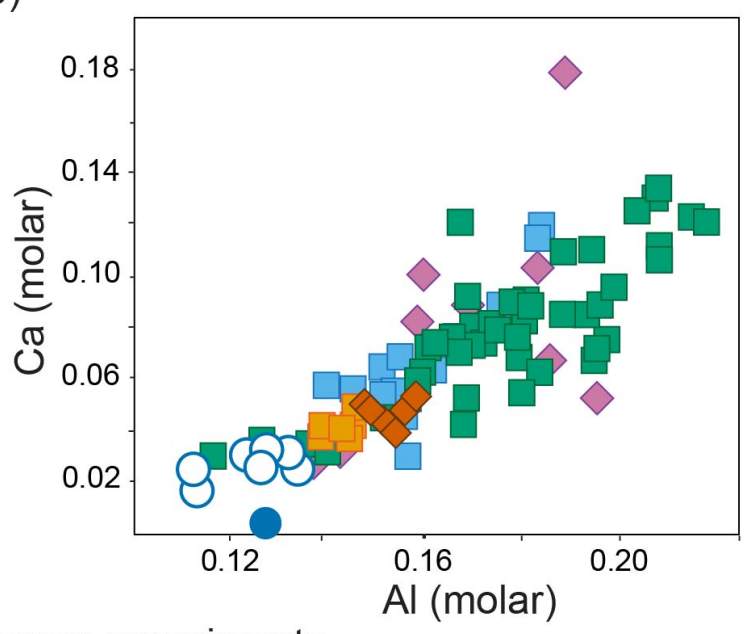

(c)

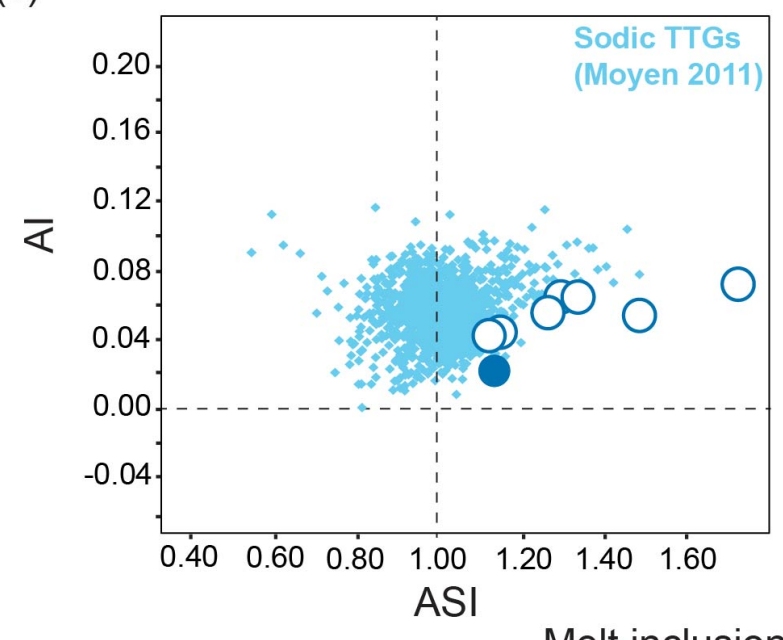

(d)

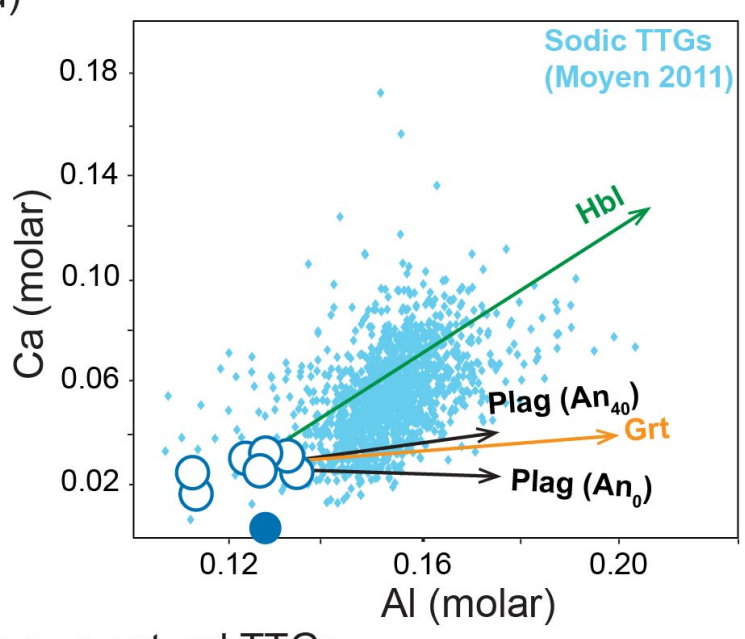

Fig. 8: ASI vs Alkalinity Index diagrams (a, c) and Molar Al vs molar Ca diagrams (b, d) of Gore Mountain MI and residual glass, experimental melts and natural TTGs. Colors for experimental melts are defined in legend Fig. 7. Enrichment vectors are visible in (d) pointing toward garnet (composition of megacrysts in Supplementary Table S1) and plagioclase and amphibole from Laurent et al. (2020). 


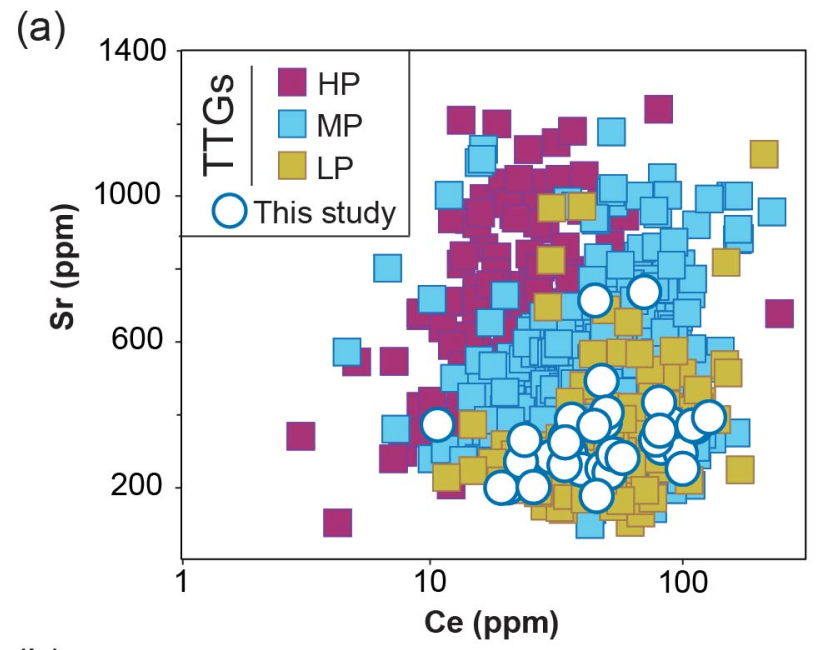

(b)
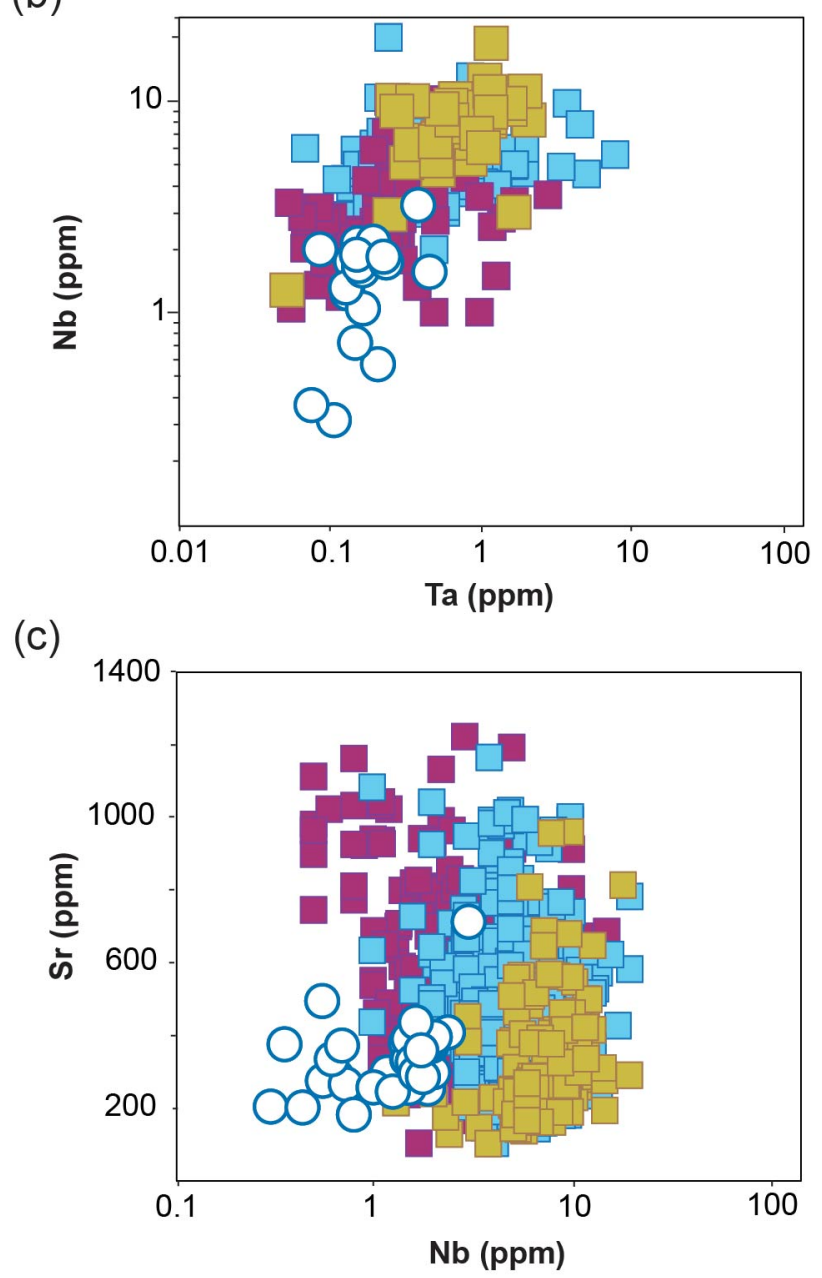

Fig. 9: Nanotrondhjemites versus TTGs. Variation diagrams of (a) Ce vs $\mathrm{Sr}$, (b) Ta vs $\mathrm{Nb}$ and (c) Nb vs Sr. Data on LP-, MP- and HP-TTGs from Moyen (2011). 


\section{SUPPLEMENTARY MATERIAL}

\section{Methods and analytical techniques}

The high resolution microstructural and microchemical investigation of the inclusions in garnet as well as the host rock was conducted on 12 thin sections, 22 doublepolished garnet chips, 8 experiments and 393 polycrystalline inclusions have been investigated and characterized using various techniques. Two FEG probes JEOL Hyperprobe JXA-8500F (at Museum für Naturkunde, Berlin and GFZ - Potsdam) were used to acquire high-resolution backscattered electron (BSE) images and energy dispersive spectrometer (EDS) elemental maps. Glass was analyzed using an electron microprobe (EMP) JEOL JXA-8200 available at the Department of Geoscience-University of Potsdam, using $15 \mathrm{kV}, 3.5 \mathrm{nA}$ beam current and a probe diameter of $1 \mu \mathrm{m}$. Alkali-loss was estimated analyzing a secondary standard of leucogranitic composition with similar $\mathrm{H}_{2} \mathrm{O}$ content, using the same analytical parameters used to measure the re-homogenized inclusions. A correction factor is then calculated by comparing the measured $\mathrm{Na}, \mathrm{K}, \mathrm{Si}$ and $\mathrm{Al}$ amounts with the known amount of $\mathrm{Na}, \mathrm{K}, \mathrm{Si}$ and $\mathrm{Al}$ in the standard glass, and this correction factor is then used to correct the alkali-loss in the results of $\mathrm{Ml}$ analyses. All these data are collected in the same analytical session. Alkali loss is in the range $16-24 \%$ relative for $\mathrm{Na}$ and $1-3 \%$ relative for $\mathrm{K}$ depending on the analytical session. This is a wellestablished procedure for alkali-rich granitic glasses (Morgan and London, 2005) and was previously used for each nanogranitoid case study (e.g. Ferrero et al., 2012; Bartoli et al., 2016). The same machine was used to characterize the mineral phases of the 
amphibolites using $15 \mathrm{kV}, 15 \mathrm{nA}$ beam current and a probe diameter of $2 \mu \mathrm{m}$ on garnet, hornblende, biotite, orthopyroxene and plagioclase. In order to have representative analyses of such megacrysts we did profiles on $\mathrm{cm}$-size portions of garnet from two different samples and spot analyses on multiple garnet chips collected from different areas of at least five pluric-cm garnets sampled directly on the field.

Micro-Raman spectroscopy investigation was performed on the inclusions using a HORIBA Jobin-Yvon Confocal LabRAM HR 800 equipped with a Peltier cooled multichannel CCD detector and an Olympus BX41 petrographic microscope. For excitation an aircooled Nd:YAG laser was used with a grating of 300 lines $/ \mathrm{mm}$, slit width set to $100 \mu \mathrm{m}$, and confocal hole set to $200 \mu \mathrm{m}(\lambda=532 \mathrm{~nm}$, laser power on sample: $2-$ $3 \mathrm{~mW}$ ). Spectra were acquired in the range 100 and $4000 \mathrm{~cm}^{-1}$ using 3 accumulations of $30 \mathrm{~s}$ each, with spectral resolution of $10 \mathrm{~cm}^{-1}$.

Re-homogenization experiments were performed with a piston cylinder press at the GFZ, Potsdam (Ferrero et al., 2015). For each experiment, 4 to 6 inclusion-bearing garnet chips were loaded with silica powder as pressure medium in a platinum capsule, then hammered shut and placed in the piston cylinder; no water was added. After quenching, the capsules were embedded in epoxy and polished to expose rehomogenized inclusions.

Trace elements in the inclusions were quantified using Laser Ablation Inductively Coupled Plasma Mass Spectrometry (LA-ICP-MS) at the Department of Earth Sciences, ETH Zürich. The analysis was performed on seven garnet chips extracted from doublepolished thick sections, targeting exclusively nanogranitoids with isometric shape and located below the surface to ensure they were representative of the original melt. 
Inclusions containing Trace Elements (TE)-rich trapped phases such as rutile, ilmenite, zircon and apatite were identified via Raman spectroscopy in advance and avoided. The data were acquired with the ETH-prototype GeoLas laser ablation system equipped with an Excimer ArF (193 nm) COMPex 102F laser source (Coherent, Germany). The repetition rate of the laser was increased to $10 \mathrm{~Hz}$, on-sample energy densities in the range of $5-10 \mathrm{~J} / \mathrm{cm}^{-2}$ and spot sizes between 10 and $30 \mu \mathrm{m}$, depending on the inclusion size. As a rule, the laser spot was kept larger than the target inclusion to ensure complete ablation. The Element XR (Thermo Fischer, Germany) sector-field ICP-MS was connected to the laser system. Calibration was done using the standard NIST SRM610, a glass standard (Jochum et al., 2011), also used for drift correction and to quantify the analyses. For the analyses of the NIST SRM 610 the energy density was $\sim 5 \mathrm{~J} / \mathrm{cm}^{2}$ and the spot size was $40 \mu \mathrm{m}$, while the other conditions remained the same as for the unknowns. Data processing was conducted offline using the software SILLS (Guillong et al., 2008) and the deconvolution routine of Halter et al. (2002). We used the average $\mathrm{Na}_{2} \mathrm{O}$ derived from EMPA as $\mathrm{Ml}$ internal standard, whereas $\mathrm{Mg}$ was used as the matrix only tracer.

Phase equilibrium modelling was conducted with Thermocalc (v.3.50, Powell and Holland, 1988), the internally consistent thermodynamic database (Holland and Powell, 2011) and in the $\mathrm{K}_{2} \mathrm{O}-\mathrm{Na}_{2} \mathrm{O}-\mathrm{CaO}-\mathrm{FeO}-\mathrm{MgO}-\mathrm{Al}_{2} \mathrm{O}_{3}-\mathrm{SiO}_{2}-\mathrm{H}_{2} \mathrm{O}-\mathrm{TiO}_{2}-\mathrm{O}-\mathrm{Cr}_{2} \mathrm{O}_{3}$ system with the following activity-compositions models of: silicate melt, garnet, orthopyroxene, clinopyroxene and olivine (Holland et al., 2018); plagioclase (Holland and Powell, 2003); clinoamphibole (Green et al., 2016); and, ilmenite (White et al., 2000). Quartz and $\mathrm{H}_{2} \mathrm{O}$ were assumed to be pure phases. All mineral abbreviations are from Holland and Powell 
(2011). We use the average olivine gabbro bulk composition of McLelland and Selleck (2011) for the protolith of the Gore Mountain garnet amphibolite. The amount of ferric and ferrous iron in the modelled system was based on the reported concentrations of $\mathrm{FeO}$ and $\mathrm{Fe}_{2} \mathrm{O}_{3}$. The amount of $\mathrm{H}_{2} \mathrm{O}$ in the modelled system was varied to constrain the observed metamorphic assemblage and mineral modes using a temperaturecomposition $\left(\mathrm{H}_{2} \mathrm{O}\right)$ diagram constructed at $1.0 \mathrm{GPa}$; this diagram was then used to determine a reasonable concentration of $\mathrm{H}_{2} \mathrm{O}$ in the peak metamorphic system and construct a pressure-temperature phase diagram.

\section{References}

Bartoli, O., Acosta-Vigil, A., Ferrero, S., and Cesare, B., 2016, Granitoid magmas preserved as melt inclusions in high-grade metamorphic rocks: American Mineralogist, v. 101, p. 1543-1559, https://doi.org/10.2138/am-2016-5541CCBYNCND.

Ferrero, S., Bartoli, O., Cesare, B., Salvioli-Mariani, E., Acosta-Vigil, A., Cavallo, A., Groppo, C., and Battiston, S., 2012, Microstructures of melt inclusions in anatectic metasedimentary rocks: Journal of Metamorphic Geology, v. 30, p. 303-322, https://doi.org/10.1111/j.1525-1314.2011.00968.x.

Ferrero, S., Wunder, B., Walczak, K., O'Brien, P. J., and Ziemann, M. A., 2015, Preserved near ultrahigh-pressure melt from continental crust subducted to mantle depths: Geology, v. 43, p. 447-450, https://doi.org/10.1130/G36534.1.

Green, E.C.R., White, R.W., Diener, J.F.A., Powell, R., Holland, T.J.B., and Palin, R.M., 2016, Activity-composition relations for the calculation of partial melting equilibria in metabasic rocks: Journal of Metamorphic Geology, v. 34, p. 845-869, doi:10.1111/jmg.12211.Guillong, M., Meier, D. L., Allan, M. M., Heinrich, C. A., and Yardley, B. W. D., 2008, SILLS: A Matlab-based program for the reduction of laser ablation ICP-MS data of homogeneous materials and inclusions: Mineralogical Association of Canada Short Course, v. 40, p. 328-333.

Halter, W. E., Pettke, T., Heinrich, C. A., and Rothen-Rutishauser, B., 2002, Major to trace element analysis of melt inclusions by laser-ablation ICP-MS: methods of quantification: Chemical Geology, v. 183, p. 63-86, https://doi.org/10.1016/S00092541(01)00372-2.

Holland, T., and Powell, R., 2003, Activity-compositions relations for phases in petrological calculations: An asymetric multicomponent formulation: Contributions to Mineralogy and Petrology, v. 145, p. 492-501, doi:10.1007/s00410-003-0464-z. 
Holland, T.J.B., and Powell, R., 2011, An improved and extended internally consistent thermodynamic dataset for phases of petrological interest, involving a new equation of state for solids: Journal of Metamorphic Geology, v. 29, p. 333-383, doi:10.1111/j.1525-1314.2010.00923.x.

Holland, T.J.B., Green, E.C.R., and Powell, R., 2018, Melting of peridotites through to granites: A simple thermodynamic model in the system KNCFMASHTOCr: Journal of Petrology, v. 59, p. 881-900, doi:10.1093/petrology/egy048.Jochum, K. P., Weis, U., Stoll, B., Kuzmin, D., Yang, Q., Raczek, I., Jacob, D. E., Stracke, A., Birbaum, K., Frick, D. A., Günther, D., and Enzweiler, J., 2011, Determination of reference values for NIST SRM 610-617 glasses following ISO Guidelines: Geostandards and Geoanalytical Research, v. 35, p. 397-429, https://doi.org/10.1111/j.1751908X.2011.00120.X.

McLelland, J. M., and Selleck, B. W., 2011, Megacrystic Gore Mountain-type garnets in the Adirondack Highlands: Age, origin, and tectonic implications: Geosphere, v. 7, p. 1194-1208, https://doi.org/10.1130/GES00683.1.Morgan VI, G.B., and London, D., 2005, Effect of current density on the electron micro-probe analysis of alkali aluminosilicate glasses: American Mineralogist, v. 90, p. 1131-1138, https://doi.org/10.2138/am.2005.1769.

Powell, R., and Holland, T.J.B., 1988, An internally consistent dataset with uncertainties and correlations: 3 . Applications to geobarometry, worked examples and a computer program: Journal of Metamorphic Geology, v. 6, p. 173-204, doi:10.1111/j.1525-1314.1988.tb00415.x.

White, R. W., Powell, R., Holland, T. J. B., and Worley, B. A., 2000, The effect of $\mathrm{TiO}_{2}$ and $\mathrm{Fe}_{2} \mathrm{O}_{3}$ on metapelitic assemblages at greenschist and amphibolite facies conditions: mineral equilibria calculations in the system $\mathrm{K}_{2} \mathrm{O}-\mathrm{FeO}-\mathrm{MgO}_{-}-\mathrm{Al}_{2} \mathrm{O}_{3}-\mathrm{SiO}_{2}-\mathrm{H}_{2} \mathrm{O}-$ $\mathrm{TiO}_{2}-\mathrm{Fe}_{2} \mathrm{O}_{3}$ : Journal of Metamorphic Geology, v. 18, p. 497-511. 


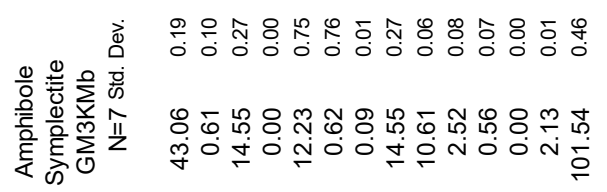

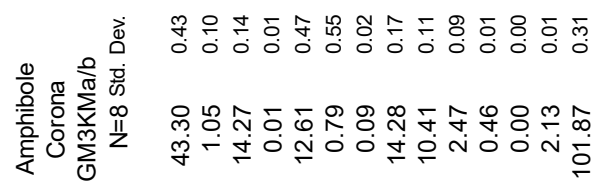

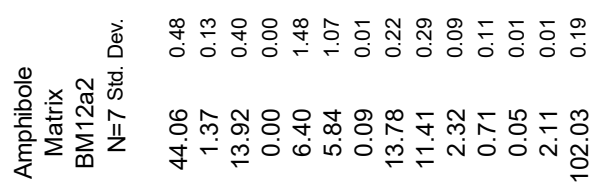

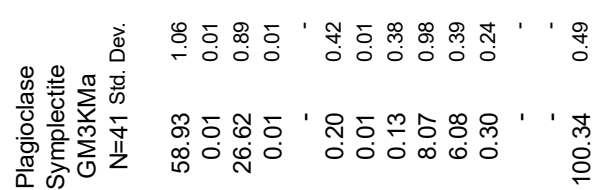

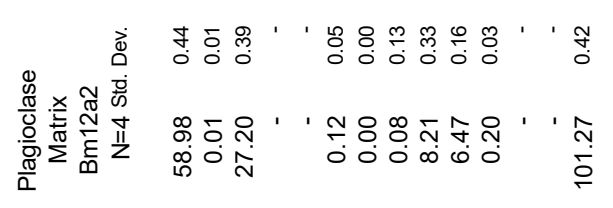

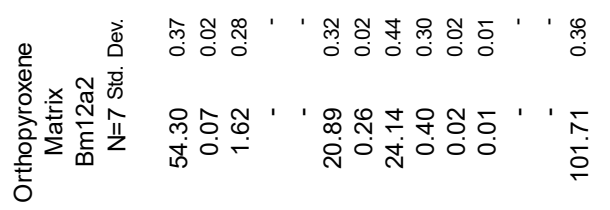

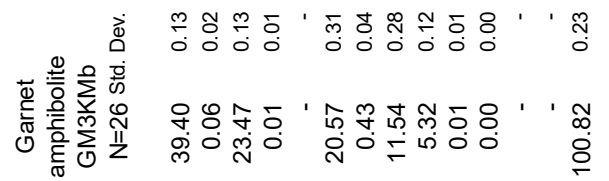

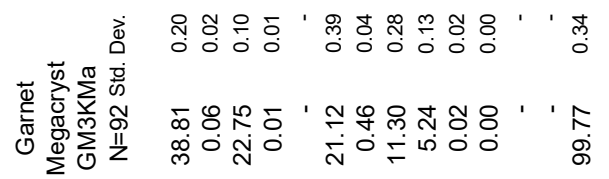

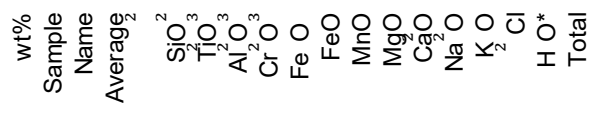

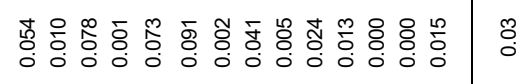

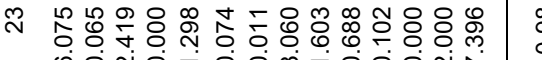

oino

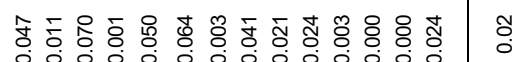

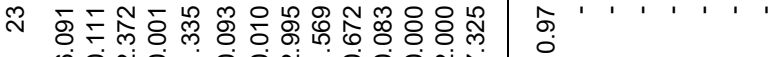

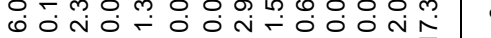

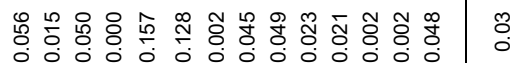

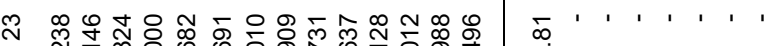

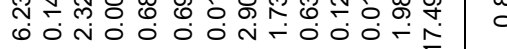

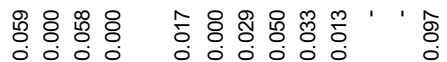

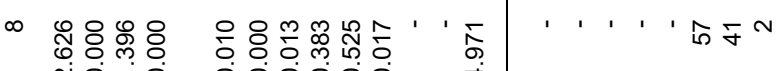

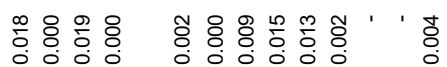

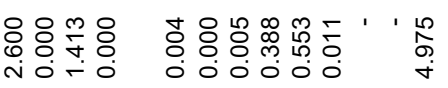

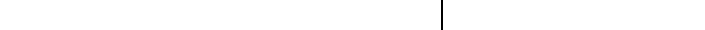

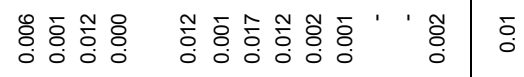

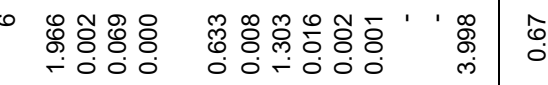

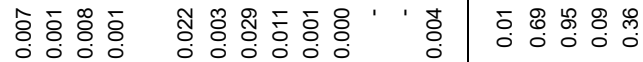

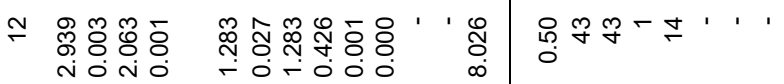

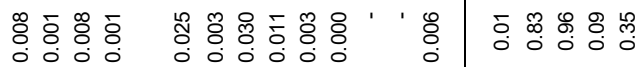

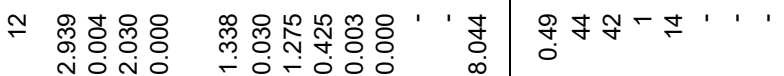

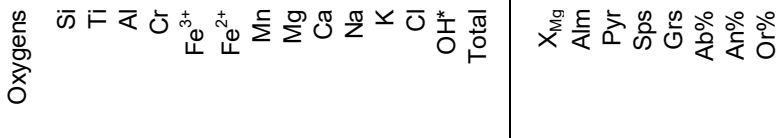


Table S1: Average electron microprobe analyses of main phases in garnet amphibolites. Amphiboles based on 23 oxygens with $\mathrm{Fe}^{2+} / \mathrm{Fe}^{3+}$ estimation assuming $\Sigma 13$ cations except for Fe-Mg-Mn amphiboles where $\Sigma 15$ is applied. $\mathrm{H}_{2} \mathrm{O}$ calculated to the basis of 23 oxygens with $2(\mathrm{OH}, \mathrm{F}, \mathrm{Cl})$ assumed. 


\begin{tabular}{|c|c|c|c|c|c|c|c|c|c|c|c|c|c|c|c|c|c|c|c|c|c|c|}
\hline Analyses & 1 & 2 & 3 & 4 & 5 & 6 & 7 & 8 & 9 & 10 & 11 & 12 & 13 & 14 & 15 & 16 & 17 & 18 & 19 & 20 & 21 & 22 \\
\hline (ppm) & b.l.d & 6.3 & b.I.d & b.I.d & b.l.d & 23.4 & b.l.d & b.l.d & b.l.d & b.l.d & b.l.d & b.l.d & b.l.d & b.l.d & b.l.d & b.l.d & b.I.d & b.l.d & b.l.d & b.l.d & b.l.d & 9.1 \\
\hline B & b.l.d & b.I.d & b.I.d & 13.6 & b.I.d & 24.4 & b.l.d & b.l.d & b.I.d & b.l.d & b.l.d & b.l.d & 11.5 & b.l.d & 16.0 & b.l.d & b.l.d & b.l.d & b.l.d & b.l.d & b.l.d & 10.5 \\
\hline$P$ & 1360 & 516 & 906 & 347 & b.I.d & b.l.d & 602 & b.l.d & b.l.d & 1677 & 233 & b.l.d & 1193 & 3100 & b.l.d & b.l.d & b.l.d & 922 & 1739 & 937 & 789 & 565 \\
\hline $\mathrm{Ti}$ & 14990 & 16541 & 18664 & 22263 & 10889 & 24260 & 38336 & 7657 & 27809 & 42949 & 10821 & 16234 & 9310 & 5072 & 7324 & 11950 & 25513 & 27254 & 41378 & 23419 & 20591 & 18944 \\
\hline V & 44 & 9 & 125 & 80 & 24 & 270 & 293 & 12 & 189 & 114 & 51 & 76 & 127 & 240 & 93 & 147 & 172 & 231 & 220 & 136 & 250 & 161 \\
\hline $\mathrm{Cr}$ & b.l.d & b.l.d & b.l.d & b.l.d & b.I.d & b.l.d & b.l.d & b.l.d & b.l.d & b.l.d & b.l.d & b.I.d & b.I.d & b.l.d & b.I.d & b.I.d & b.I.d & b.I.d & b.I.d & b.l.d & b.l.d & b.I.d \\
\hline $\mathrm{Ni}$ & 63 & 62 & 33 & 53 & 38 & 102 & 73 & 39 & 45 & b.l.d & b.l.d & 60 & 55 & 1270 & 83 & b.I.d & b.l.d & 98 & 176 & 89 & b.I.d & 38 \\
\hline $\mathrm{Zn}$ & 55 & b.l.d & 120 & 14 & b.l.d & 13 & b.l.d & b.l.d & 264 & 19 & b.l.d & b.l.d & 112 & 520 & b.l.d & b.I.d & 145 & 254 & b.l.d & b.l.d & 267 & 260 \\
\hline $\mathrm{Rb}$ & b.l.d & b.l.d & b.I.d & b.l.d & 6.2 & 14.8 & 9.0 & 5.3 & 4.5 & 20.0 & 8.8 & 10.8 & 34.4 & 11.3 & 10.0 & 10.0 & 16.7 & 4.2 & 29.5 & 43.8 & 16.6 & 4.8 \\
\hline $\mathrm{Sr}$ & 290 & 198 & 280 & 727 & 332 & 375 & 808 & 197 & 208 & 486 & 197 & 191 & 267 & 246 & 258 & 249 & 400 & 208 & 704 & 327 & 371 & 305 \\
\hline $\mathrm{Zr}$ & 344 & 107 & 1468 & 1770 & 1102 & 940 & 2373 & 893 & 1282 & 2600 & 1021 & 1018 & 285 & 1521 & 1003 & 1138 & 1590 & 863 & 1932 & 974 & 1768 & 1469 \\
\hline $\mathrm{Nb}$ & 1.22 & 0.43 & 0.67 & b.l.d & 1.58 & 2.01 & 0.34 & b.l.d & 0.25 & 0.57 & 0.31 & 0.32 & 0.57 & 1.97 & 0.75 & 1.04 & 2.49 & 0.77 & 3.18 & 1.54 & 1.52 & 1.72 \\
\hline Cs & b.l.d & 0.1 & b.I.d & b.l.d & b.l.d & b.I.d & b.l.d & b.l.d & b.l.d & 0.6 & b.l.d & b.l.d & b.l.d & b.I.d & b.l.d & b.l.d & b.I.d & b.l.d & b.l.d & b.I.d & b.I.d & 0.2 \\
\hline $\mathrm{Ba}$ & 7 & 10 & 23 & 48 & 132 & 213 & 190 & 78 & 63 & 249 & 120 & 114 & 176 & 138 & 178 & 108 & 296 & 93 & 228 & 265 & 140 & 122 \\
\hline La & 18.3 & 15.0 & 19.5 & 30.4 & 14.9 & 17.8 & 24.1 & 13.1 & 69.7 & 23.6 & 10.3 & 7.9 & 7.7 & 15.4 & 10.2 & 14.9 & 17.9 & 18.8 & 14.4 & 12.4 & 26.6 & 23.1 \\
\hline $\mathrm{Ce}$ & 34.6 & 24.7 & 29.1 & 68.0 & 33.2 & 47.4 & 53.2 & 19.5 & 135.7 & 46.1 & 18.4 & 20.2 & 22.1 & 38.3 & 32.8 & 46.4 & 48.3 & 61.8 & 43.5 & 33.7 & 86.4 & 79.6 \\
\hline $\mathrm{Sm}$ & 1.79 & 7.27 & 3.24 & 4.76 & b.l.d & 2.14 & 5.02 & 0.60 & 8.96 & 2.67 & 1.01 & 1.15 & 3.09 & 3.68 & 3.42 & 8.94 & 6.82 & 18.35 & 5.03 & 1.80 & 12.42 & 9.36 \\
\hline Eu & 0.65 & 2.46 & 1.74 & 1.78 & 0.61 & 1.92 & 3.02 & b.l.d & 4.71 & 1.91 & 0.34 & 0.42 & 1.86 & b.l.d & 1.00 & 1.56 & 2.69 & 8.71 & 0.93 & b.l.d & 3.18 & 4.05 \\
\hline $\mathrm{Gd}$ & 2.73 & 7.63 & 6.94 & 5.65 & 1.63 & 10.02 & 11.85 & b.l.d & 17.47 & 7.25 & 3.01 & b.l.d & 6.78 & b.l.d & 5.66 & 0.86 & b.l.d & 16.10 & b.l.d & 1.55 & 7.17 & 8.88 \\
\hline $\mathrm{Hf}$ & 11 & 4 & 35 & 44 & 35 & 35 & 70 & 17 & 25 & 51 & 22 & 26 & 5 & 35 & 27 & 30 & 64 & 14 & 38 & 22 & 44 & 36 \\
\hline $\mathrm{Ta}$ & 0.13 & b.l.d & b.I.d & b.l.d & b.I.d & b.I.d & 0.34 & b.l.d & b.l.d & 0.21 & 0.11 & b.l.d & b.l.d & b.l.d & b.l.d & 0.17 & b.l.d & b.l.d & 0.39 & 0.46 & b.l.d & 0.14 \\
\hline $\mathrm{Pb}$ & 10 & 9 & 10 & 20 & 18 & 19 & 29 & 7 & 17 & 22 & 10 & 8 & 12 & 20 & 11 & 12 & 21 & 10 & 29 & 12 & 18 & 16 \\
\hline Th & 7 & 11 & 20 & 14 & 10 & 11 & 42 & 9 & 26 & 23 & 9 & 8 & 1 & 12 & 9 & 11 & 13 & 4 & 31 & 4 & 17 & 12 \\
\hline U & 2 & 6 & 10 & 1 & 11 & 11 & 4 & 5 & 24 & 20 & 6 & 6 & 3 & 12 & 7 & 10 & 15 & 8 & 27 & 7 & 16 & 13 \\
\hline
\end{tabular}

Table S2: Trace elements measured on nanogranitoids from Gore Mountain. B.I.d.= Below Limit of detection. 


\begin{tabular}{|c|c|c|c|c|c|c|c|c|c|c|c|c|c|c|c|c|c|c|c|c|c|c|}
\hline Analyses & 23 & 24 & 25 & 26 & 27 & 28 & 29 & 30 & 31 & 32 & 33 & 34 & 35 & 36 & 37 & 38 & 39 & 40 & 41 & 42 & 43 & $\frac{\text { Average }}{(n=43)}$ \\
\hline $\mathrm{Li}(\mathrm{ppm})$ & 5.1 & b.l.d & b.l.d & b.l.d & 19.0 & b.I.d & b.I.d & b.l.d & 7.7 & b.l.d & b.l.d & b.l.d & b.l.d & b.l.d & b.l.d & b.l.d & b.l.d & 10.1 & 9.0 & 8.2 & b.l.d & 16.2 \\
\hline B & b.l.d & b.l.d & b.l.d & b.l.d & b.l.d & b.l.d & b.l.d & 13.3 & 9.5 & 10.7 & b.l.d & b.l.d & b.l.d & b.l.d & b.l.d & b.l.d & b.l.d & b.l.d & b.l.d & 13.6 & 23.5 & 18.8 \\
\hline$P$ & 432 & 1157 & 477 & 1221 & b.l.d & 737 & 1987 & 440 & 1215 & b.l.d & 1167 & 634 & b.l.d & 374 & 915 & 1093 & 1474 & b.l.d & b.l.d & 356 & 267 & 759 \\
\hline Sc & 31 & 45 & 170 & 101 & 30 & 64 & b.I.d & 41 & 40 & 77 & 46 & 194 & 325 & 63 & 126 & 121 & 58 & b.l.d & b.l.d & 14 & 49 & 84 \\
\hline $\mathrm{Ti}$ & 17509 & 43290 & 39450 & 22834 & 21972 & 10360 & 15174 & 23379 & 18393 & 13792 & 31767 & 33223 & 22488 & 11415 & 32526 & 18099 & 21350 & 14377 & 13016 & 20491 & 23419 & 21687 \\
\hline V & 157 & 215 & 361 & 111 & b.l.d & 159 & 294 & 183 & 108 & 112 & 235 & 207 & 677 & 57 & 84 & 169 & 167 & 120 & 15 & 190 & 220 & 164 \\
\hline $\mathrm{Cr}$ & b.l.d & b.l.d & b.l.d & 21 & b.I.d & b.l.d & b.l.d & 16 & b.l.d & b.I.d & b.l.d & b.l.d & b.l.d & b.l.d & b.l.d & b.l.d & b.I.d & b.l.d & b.l.d & b.l.d & b.l.d & 32.2 \\
\hline $\mathrm{Ni}$ & 24 & 55 & 193 & 97 & 44 & 46 & 1474 & 53 & 77 & 39 & 117 & b.I.d & b.l.d & 39 & 107 & 79 & 38 & 875 & 151 & 867 & b.l.d & 168 \\
\hline $\mathrm{Cu}$ & 2 & 13 & 19 & 7 & 2 & 5 & b.l.d & 4 & 5 & 7 & 6 & 10 & b.l.d & 8 & 8 & 11 & 9 & 4 & 15 & 5 & b.l.d & 10 \\
\hline $\mathrm{Zn}$ & 188 & 440 & b.l.d & 125 & b.l.d & 360 & 234 & 165 & 40 & b.l.d & 356 & 365 & b.l.d & 59 & 102 & b.l.d & 336 & 97 & 44 & 147 & b.l.d & 131 \\
\hline $\mathrm{Rb}$ & 4.3 & b.I.d & 4.0 & 2.4 & 6.5 & 5.0 & 7.4 & 26.2 & 17.2 & 9.5 & 20.3 & 11.8 & 41.6 & 5.2 & 2.4 & 1.6 & 1.8 & 3.2 & b.l.d & 9.6 & 14.1 & 10.7 \\
\hline $\mathrm{Sr}$ & 290 & 248 & 383 & 237 & 326 & 174 & 453 & 366 & 381 & 320 & 327 & 390 & 347 & 367 & 364 & 288 & 387 & 277 & 365 & 428 & 351 & 332 \\
\hline$Z r$ & 1487 & 2521 & 2589 & 1027 & 894 & 742 & 1656 & 1899 & 1728 & 1452 & 1639 & 2008 & 983 & 567 & 2433 & 1947 & 2280 & 1568 & 620 & 1327 & 1835 & 1470 \\
\hline $\mathrm{Nb}$ & 2.10 & 1.58 & 0.26 & 1.30 & 1.56 & 0.82 & 2.74 & 1.97 & 1.57 & 1.65 & 0.64 & 1.77 & 1.11 & 0.36 & 0.72 & 1.70 & 2.14 & 1.86 & 0.12 & 1.71 & 1.82 & 1.30 \\
\hline Cs & b.l.d & b.l.d & b.l.d & b.l.d & b.I.d & b.l.d & b.l.d & b.l.d & b.l.d & b.l.d & b.I.d & b.l.d & b.l.d & b.l.d & b.l.d & b.I.d & b.I.d & b.l.d & b.l.d & 0.3 & b.l.d & 0.5 \\
\hline $\mathrm{Ba}$ & 108 & 47 & 91 & 63 & 139 & 88 & 227 & 213 & 152 & 161 & 261 & 179 & 335 & 72 & 47 & 66 & 54 & 58 & 10 & 128 & 235 & 134 \\
\hline La & 31.0 & 30.6 & 40.1 & 24.0 & 8.1 & 15.1 & 26.3 & 27.8 & 13.9 & 12.4 & 21.7 & 30.4 & 26.6 & 4.4 & 21.3 & 22.4 & 48.3 & 20.3 & 8.0 & 23.5 & 23.0 & 22.6 \\
\hline $\mathrm{Ce}$ & 95.0 & 96.7 & 111.1 & 49.6 & 22.8 & 44.0 & 74.8 & 106.1 & 35.1 & 33.0 & 75.8 & 110.1 & 87.7 & 10.3 & 43.1 & 51.2 & 123.1 & 55.8 & 10.2 & 77.9 & 78.5 & 59.6 \\
\hline $\operatorname{Pr}$ & 13.4 & 17.6 & 18.3 & 4.4 & 2.5 & 6.4 & 9.1 & 18.2 & 4.2 & 3.3 & 15.6 & 21.1 & 15.5 & 1.1 & 3.6 & 4.2 & 16.2 & 7.2 & 0.9 & 11.0 & 13.3 & 8.4 \\
\hline $\mathrm{Nd}$ & 55.4 & 104.7 & 102.2 & 12.7 & 4.5 & 25.3 & 31.3 & 77.2 & 13.8 & 7.2 & 84.8 & 100.6 & 85.1 & 4.9 & 10.7 & 13.4 & 64.7 & 34.5 & 2.6 & 50.3 & 70.8 & 37.0 \\
\hline $\mathrm{Sm}$ & 11.1 & 27.8 & 24.9 & 2.7 & 2.0 & 5.0 & 12.2 & 14.3 & 2.4 & 2.4 & 27.2 & 23.0 & 18.2 & 1.3 & 1.1 & 1.0 & 11.2 & 10.8 & 0.4 & 10.1 & 13.8 & 8.5 \\
\hline $\mathrm{Eu}$ & 4.1 & 13.6 & 11.3 & 0.9 & b.l.d & 2.8 & 2.4 & 6.3 & 1.1 & 0.8 & 11.9 & 13.5 & 8.2 & 0.8 & 1.1 & 0.9 & 4.8 & 4.2 & b.l.d & 3.8 & 6.8 & 3.6 \\
\hline Gd & 7.9 & 24.5 & 32.6 & 4.2 & b.l.d & 5.1 & 3.3 & 12.9 & 4.4 & 1.7 & 20.6 & 22.3 & 8.3 & 2.2 & 4.1 & 6.1 & 10.5 & 5.0 & b.l.d & 8.1 & 9.7 & 8.0 \\
\hline $\mathrm{Hf}$ & 36 & 42 & 65 & 29 & 22 & 16 & 45 & 44 & 39 & 38 & 30 & 44 & 17 & 17 & 36 & 42 & 58 & 38 & 12 & 37 & 39 & 34.2 \\
\hline $\mathrm{Ta}$ & 0.15 & b.l.d & b.l.d & 0.13 & b.l.d & b.l.d & b.l.d & 0.09 & 0.17 & 0.16 & b.l.d & b.l.d & b.l.d & 0.08 & 0.15 & b.l.d & 0.20 & 0.15 & b.l.d & 0.24 & 0.23 & 0.33 \\
\hline $\mathrm{Pb}$ & 14 & 16 & 18 & 12 & 19 & 15 & 24 & 17 & 16 & 15 & 13 & 19 & 20 & 11 & 12 & 14 & 19 & 12 & 13 & 20 & 19 & 16 \\
\hline Th & 13 & 11 & 19 & 10 & 6 & 6 & 14 & 15 & 9 & 10 & 7 & 14 & 6 & 10 & 30 & 12 & 21 & 5 & 14 & 10 & 17 & 14 \\
\hline$U$ & 16 & 15 & 20 & 11 & 7 & 7 & 15 & 14 & 9 & 10 & 8 & 13 & 12 & 2 & 14 & 15 & 25 & 6 & 8 & 13 & 15 & 11 \\
\hline
\end{tabular}

Table S2 (continued). Trace elements measured on nanogranitoids from Gore Mountain. 
Table S3 (see separate supplementary file Table S3_H2O-present melting experiments from literature). Compilation of experimental melts from $\mathrm{H}_{2} \mathrm{O}$-present melting of mafic starting composition and measured melt composition from the present study, recalculated to 100 . 


\begin{tabular}{|c|c|c|c|c|c|c|c|c|c|c|c|c|c|c|c|c|}
\hline \multirow{4}{*}{\multicolumn{2}{|c|}{$\begin{array}{l}\text { Reference } \begin{array}{c}\text { McLelland and } \\
\text { Selleck, } 2011\end{array} \\
\text { Experiment type } \\
\text { Starting Olivine gabbro } \\
\text { composition }\end{array}$}} & \multicolumn{3}{|c|}{ Beard and Lofgren, 1991} & \multicolumn{3}{|c|}{ Laurie ans Stevens, 2012} & \multicolumn{5}{|c|}{ Winther, 1996} & \multicolumn{2}{|c|}{$\begin{array}{c}\text { Winther and Newton, } \\
1991\end{array}$} & \multicolumn{2}{|c|}{$\begin{array}{c}\text { Johnston and Wyllie, } \\
1988\end{array}$} \\
\hline & & \multicolumn{3}{|c|}{ Mafic melting } & \multicolumn{3}{|c|}{ Mafic melting } & \multicolumn{4}{|c|}{ Mafic melting } & & \multicolumn{2}{|c|}{ Mafic melting } & \multicolumn{2}{|c|}{ Crystallization } \\
\hline & & \multicolumn{2}{|c|}{ Greenstones } & $\begin{array}{c}\mathrm{Hbl} \\
\text { hornfels }\end{array}$ & \multicolumn{3}{|c|}{ Basalts } & \multicolumn{4}{|c|}{ Archean tholeiite and MORB } & & \multirow[t]{2}{*}{$\begin{array}{l}\text { Hat Creek } \\
\text { Basalt }\end{array}$} & \multirow{2}{*}{$\begin{array}{l}\text { Average } \\
\text { Archean } \\
\text { Tholeiite }\end{array}$} & \multicolumn{2}{|c|}{ Trondhjemite } \\
\hline & & 478 & 571 & 466 & DSE4 & $C-F 2 b$ & MORB & AAT & AAT5 & АAT3 & AAT1 & AAT3/2 & & & $A$ & $B$ \\
\hline $\begin{array}{l}w t \% \\
\mathrm{SiO}^{2}\end{array}$ & 46.86 & 52.47 & 51.39 & 49.48 & 50.00 & 46.50 & 50.50 & 49.10 & 49.20 & 49.10 & 49.80 & 48.50 & 48.20 & 49.20 & 71.09 & 72.21 \\
\hline $\mathrm{TiO}_{3}^{2}$ & 0.84 & 1.74 & 1.55 & 1.18 & 2.50 & 2.00 & 1.60 & 1.30 & 1.35 & 1.25 & 1.03 & 1.14 & 0.85 & 1.19 & 0.20 & 0.23 \\
\hline $\mathrm{Al}^{2} \mathrm{O}^{3}$ & 16.91 & 15.29 & 15.82 & 17.76 & 12.80 & 15.00 & 15.30 & 14.80 & 13.80 & 15.70 & 16.40 & 16.60 & 19.30 & 15.60 & 16.45 & 16.15 \\
\hline $\mathrm{FeO}$ & 0.23 & & & & & & & & & & & & & & 0.33 & \\
\hline $\mathrm{FeO}$ & 11.10 & 11.79 & 12.23 & 12.49 & 16.20 & 13.80 & 10.50 & 14.20 & 14.80 & 13.70 & 12.70 & 13.40 & 8.94 & 13.60 & 1.05 & 0.89 \\
\hline $\mathrm{MnO}$ & 0.15 & 0.22 & 0.26 & 0.26 & 0.30 & 0.20 & 0.00 & 0.20 & 0.18 & 0.18 & 0.13 & 0.09 & 0.11 & 0.15 & 0.03 & 0.04 \\
\hline $\mathrm{MgO}$ & 10.54 & 5.29 & 4.42 & 4.74 & 5.70 & 7.20 & 7.50 & 6.50 & 6.19 & 6.86 & 7.09 & 7.42 & 8.72 & 6.89 & 0.60 & 0.58 \\
\hline $\mathrm{Ca}_{2}^{2} \mathrm{O}$ & 8.25 & 9.21 & 8.95 & 10.90 & 9.60 & 9.20 & 11.50 & 11.40 & 12.10 & 10.60 & 9.88 & 10.50 & 10.50 & 10.80 & 2.76 & 2.90 \\
\hline $\mathrm{Na}^{2} \mathrm{O}$ & 2.56 & 2.55 & 3.30 & 1.96 & 2.00 & 2.30 & 2.60 & 2.30 & 2.10 & 2.40 & 2.67 & 2.23 & 3.11 & 2.35 & 4.93 & 4.73 \\
\hline K O & 0.56 & 0.16 & 0.37 & 0.15 & 0.01 & 0.90 & 0.20 & 0.30 & 0.29 & 0.30 & 0.26 & 0.17 & 0.39 & 0.26 & 2.33 & 2.23 \\
\hline $\mathrm{P}_{2} \mathrm{O}_{5}$ & 0.10 & 0.29 & 0.3 & 0.3 & 0.3 & 0.1 & 0.1 & & & & & & & & 0.05 & \\
\hline Total & 98.10 & 99.01 & 98.59 & 99.22 & 99.41 & 97.20 & 99.80 & 100.10 & 100.01 & 100.09 & 99.96 & 100.05 & 100.12 & 100.04 & 99.82 & 99.96 \\
\hline $\mathrm{HO}$ & 0.44 & & - & 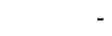 & - & - & & - & 5.12 & 2.68 & 0.78 & 3.01 & & - & & \\
\hline $\mathrm{Si}$ & 0.780 & 0.873 & 0.855 & 0.824 & 0.832 & 0.774 & 0.840 & 0.817 & 0.819 & 0.817 & 0.829 & 0.807 & 0.802 & 0.819 & 1.183 & 1.202 \\
\hline $\mathrm{Ti}$ & 0.011 & 0.022 & 0.019 & 0.015 & 0.031 & 0.025 & 0.020 & 0.016 & 0.017 & 0.016 & 0.013 & 0.014 & 0.011 & 0.015 & 0.003 & 0.003 \\
\hline Al & 0.166 & 0.150 & 0.155 & 0.174 & 0.126 & 0.147 & 0.150 & 0.145 & 0.135 & 0.154 & 0.161 & 0.163 & 0.189 & 0.153 & 0.161 & 0.158 \\
\hline $\mathrm{Fe} 3$ & 0.001 & 0.000 & 0.000 & 0.000 & 0.000 & 0.000 & 0.000 & 0.000 & 0.000 & 0.000 & 0.000 & 0.000 & 0.000 & 0.000 & 0.002 & 0.000 \\
\hline $\mathrm{Fe} 2$ & 0.157 & 0.167 & 0.174 & 0.178 & 0.230 & 0.195 & 0.146 & 0.200 & 0.209 & 0.193 & 0.179 & 0.188 & 0.126 & 0.191 & 0.015 & 0.013 \\
\hline $\mathrm{Mg}$ & 0.262 & 0.131 & 0.110 & 0.118 & 0.141 & 0.179 & 0.186 & 0.161 & 0.154 & 0.170 & 0.176 & 0.184 & 0.216 & 0.171 & 0.015 & 0.014 \\
\hline $\mathrm{Ca}$ & 0.147 & 0.164 & 0.160 & 0.194 & 0.171 & 0.164 & 0.205 & 0.203 & 0.216 & 0.189 & 0.176 & 0.187 & 0.187 & 0.193 & 0.049 & 0.052 \\
\hline $\mathrm{Na}$ & 0.041 & 0.041 & 0.053 & 0.032 & 0.032 & 0.037 & 0.042 & 0.037 & 0.034 & 0.039 & 0.043 & 0.036 & 0.050 & 0.038 & 0.080 & 0.076 \\
\hline $\mathrm{K}$ & 0.006 & 0.002 & 0.004 & 0.002 & 0.000 & 0.010 & 0.002 & 0.003 & 0.003 & 0.003 & 0.003 & 0.002 & 0.004 & 0.003 & 0.025 & 0.024 \\
\hline $\mathrm{P}$ & 0.001 & 0.002 & 0.002 & 0.002 & 0.002 & 0.001 & 0.001 & 0.000 & 0.000 & 0.000 & 0.000 & 0.000 & 0.000 & 0.000 & 0.000 & 0.000 \\
\hline ASI & 0.85 & 0.72 & 0.72 & 0.77 & 0.62 & 0.70 & 0.60 & 0.60 & 0.54 & 0.67 & 0.72 & 0.72 & 0.78 & 0.66 & 1.05 & 1.04 \\
\hline $\mathrm{Al} / \mathrm{Ca}$ & 1.13 & 0.91 & 0.97 & 0.90 & 0.73 & 0.90 & 0.73 & 0.71 & 0.63 & 0.81 & 0.91 & 0.87 & 1.01 & 0.79 & 3.28 & 3.06 \\
\hline${ }_{2} \mathrm{Mg \#}$ & 0.63 & 0.44 & 0.39 & 0.40 & 0.38 & 0.48 & 0.56 & 0.45 & 0.42 & 0.47 & 0.50 & 0.50 & 0.63 & 0.47 & 0.50 & 0.53 \\
\hline
\end{tabular}

Where $\mathrm{Fe} O$ is not reported $\mathrm{FeO}$ is the total $\mathrm{Fe}$

Table S4: Gabbro protolith composition versus starting composition of experiments reported in Fig. 7 and 8 in the main paper. 


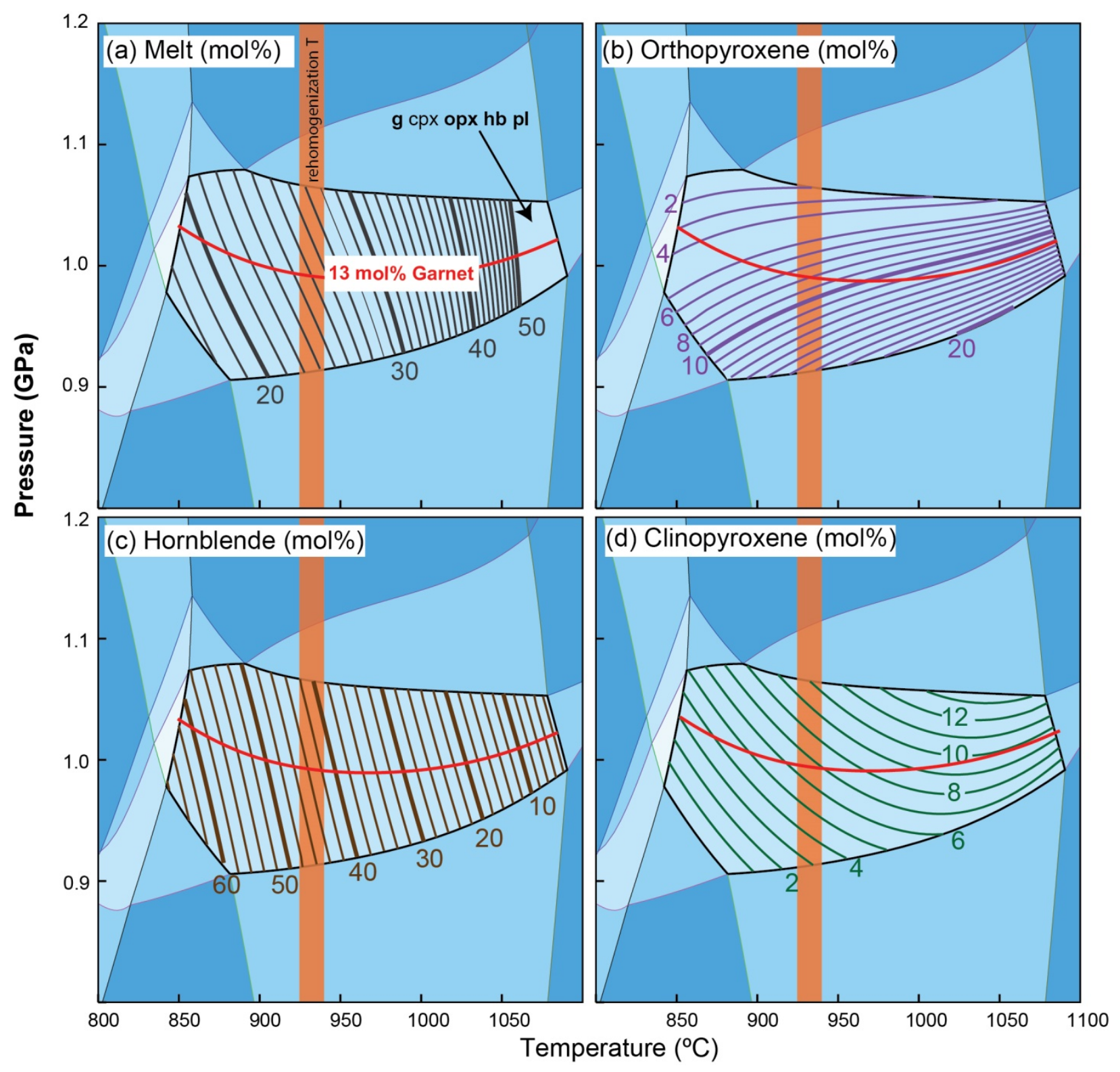

Figure S1: Diagrams showing the modal proportions of the melt and mineral phases belonging to the peak assemblage of the garnet amphibolites. 